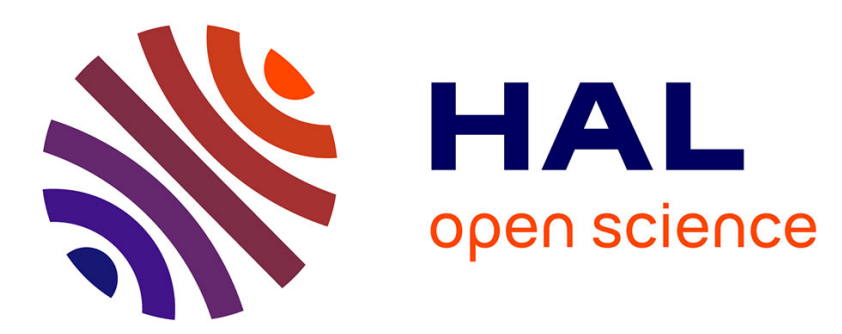

\title{
THE EFFECT OF THE INCREMENTAL R\&D TAX CREDIT ON THE PRIVATE FUNDING OF R\&D: AN ECONOMETRIC EVALUATION ON FRENCH FIRM LEVEL DATA
}

Emmanuel Duguet

\section{To cite this version:}

Emmanuel Duguet. THE EFFECT OF THE INCREMENTAL R\&D TAX CREDIT ON THE PRIVATE FUNDING OF R\&D: AN ECONOMETRIC EVALUATION ON FRENCH FIRM LEVEL DATA. 2012. halshs-00674546

\section{HAL Id: halshs-00674546 \\ https://shs.hal.science/halshs-00674546}

Preprint submitted on 27 Feb 2012

HAL is a multi-disciplinary open access archive for the deposit and dissemination of scientific research documents, whether they are published or not. The documents may come from teaching and research institutions in France or abroad, or from public or private research centers.
L'archive ouverte pluridisciplinaire HAL, est destinée au dépôt et à la diffusion de documents scientifiques de niveau recherche, publiés ou non, émanant des établissements d'enseignement et de recherche français ou étrangers, des laboratoires publics ou privés. 
DOCUMENT DE TRAVAIL

\title{
THE EFFECT OF THE INCREMENTAL R\&D TAX CREDIT ON THE PRIVATE FUNDING OF R\&D: AN ECONOMETRIC EVALUATION ON FRENCH FIRM LEVEL DATA
}

\author{
Emmanuel DUGUET ${ }^{1}$ \\ Université Paris Est, ERUDITE (EA 437) and TEPP (FR CNRS 3126)
}

\footnotetext{
1 Address: Université Paris-Est, ERUDITE, Mail des Mèches, 61 avenue du Général de Gaulle, 94010 Créteil cedex. Email: emmanuel.duguet@u-pec.fr. The author thanks B. Guédou for his suggestions and comments on a previous version of this paper, as well as the participants to the EPEE Seminar (University of Evry), to the " Economics and Econometrics of Innovation » Seminar (Universities of Paris I-CES, Paris II-ERMES and ENST-SES) and to the OECD « TIP Workshop » (December 2007, Paris).
} 


\title{
Résumé
}

Nous étudions, sur données d'entreprises, si le crédit d'impôt recherche (CIR) en accroissement a augmenté le financement privé de la recherche et développement sur la décennie 1993-2003. Afin de répondre à cette question, nous utilisons les enquêtes annuelles du Ministère de la Recherche, ainsi que les données fiscales individuelles relatives au CIR. La question principale est de déterminer si les entreprises auraient quand même augmenté leur financement privé en l'absence d'incitation fiscale. Nous utilisons une méthodologie à la Rubin. Dans un premier temps, nous étudions les déterminants de la probabilité d'obtention du crédit d'impôt recherche, c'est-à-dire le processus de sélection des participants à cette mesure. Nous trouvons que la probabilité d'obtention du crédit d'impôt recherche en accroissement augmente avec le ratio R\&D/Ventes et décroît avec l'obtention de subventions à la R\&D. Après avoir évalué la probabilité d'obtention du CIR de chaque entreprise nous corrigeons les biais de sélection. Dans un second temps, nous évaluons l'effet du CIR en accroissement sur le financement privé de la recherche (net de subventions attribuées par d'autres sources). Nous trouvons que, globalement, le crédit d'impôt s'ajoute au financement privé de la recherche, de sorte qu'un euro de CIR mène à un accroissement d'un peu plus d'un Euro de recherche totale. Nous trouvons également que le CIR en accroissement augmente le taux de croissance du nombre de chercheurs employés dans les entreprises.

Mots-Clés : crédit d'impôt, évaluation, recherche et développement Classement JEL : H25, O32, O38

\begin{abstract}
We study, at the firm level, whether the incremental R\&D tax credit increases the private funding of

R\&D. In order to answer this question, we use the yearly surveys of the Ministry of Research over the period 1993-2003, as well as the corresponding firm-level tax files. The main issue is whether the firms would have increased their R\&D expenditures without this tax incentive. We make use of the Rubin methodology. In a first step, we study the determinants of the probability to benefit from the R\&D tax credit, that is the selection process at work in the recipients' sample. We find that the probability to obtain a R\&D tax credit increases with the $R \& D /$ Sales ratio and decreases with the direct R\&D subsidies. Once we have evaluated the probability to get the R\&D tax credit, we are able to correct for the selection bias. In a second step, we evaluate the effect of the incremental R\&D tax credit on the private funding of research (once subtracted the direct subsidies from all the ministries). We find that, overall, the tax credit adds to the private funding of R\&D: 1 Euro of tax credit would give slightly more than one Euro of total R\&D. We also find that the incremental R\&D tax credit increases the growth of the number of researchers.
\end{abstract}

Keywords: tax credit, evaluation, research and development JEL Classification: H25, O32, 038 


\section{Introduction}

The many empirical studies that have been conducted in OECD countries over the past fifteen years show that research and development significantly improves the firms' performances, however measured (Kleinknecht ed, 1996; Kleinknecht and Mohnen eds, 2002). The economic performance of a country therefore depends on its capacity to provide the right incentives to research and development $(R \& D)$ in the private sector. Unfortunately, $R \& D$ raises specific investment issues that do not always occur for physical investment. First, R\&D creates information, and it cannot always be protected efficiently from competitors. Through imitation, some firms can get a part of the benefits of their competitors' investments. Second, in some specific markets, the competition focuses on innovation itself more than on the organization of production. A firm that launches a new product gets a strategic advantage. Third, the output of research is naturally random. These three elements reduce the private incentives to perform research investments compared to physical investments. If no policy measure was to be taken, firms would show a tendency to under invest in R\&D (D'Aspremont and Jacquemin, 1988; Kamien, Muller and Zang, 1992).

In order to achieve higher incentives for $R \& D$, one needs to make this activity more profitable from the firms' viewpoint. Two types of measures have been implemented: On the one hand, enforcing stronger property rights and, on the other hand, promoting financial support to $R \& D$. The first type of measures relies on patents and brands. By forbidding imitators to get, freely, the benefits from the investments of innovators, the property rights aim to increase the gross return on R\&D. This first array of policies is often not sufficient, because it is hard to apply property rights in some lines of business. Moreover, in order to protect themselves from imitation, the firms have to incur additional secrecy costs that reduce the return on R\&D (Levin et al., 1987, Duguet and Kabla, 1998). The second type of measure is based on R\&D subsidies and R\&D tax credit. Their goal is to reduce the sunk cost of R\&D. Compared to subsidies, the fiscal regulations present some advantages and one drawback. Among the advantages, fiscal incentives apply equally to all the firms whatever their line of business or their size are; they also let the initiative of the technological choices to the market, that is to the consumers of the new products; moreover, they reduce the administrative burden to fulfilling a simple form. The main drawback, compared to subsidies, is that there is no selection of the $R \& D$ projects by an independent institution. Therefore, there is a higher probability that firms that did not need any public support for their $R \& D$ projects apply for the $R \& D$ tax credit. In this last case, it is difficult to predict the effect of the tax credit on the private funding of R\&D. 
According to a recent study (Warda, 2006), the practice of $R \& D$ tax credit is expanding among the OECD countries, from 12 countries in 1996 to 19 countries in 2005. This expansion of fiscal deductions raises the additional issue of fiscal competition among countries, which could influence the location of the private $R \& D$ laboratories. Therefore, in addition to the classic issue of the private incentives for $R \& D$, the expansion of $R \& D$ tax credit could also exert an influence over the location of the future knowledge production.

In France, the R\&D tax credit («Crédit d'Impôt Recherche », CIR) was introduced in 1983. Until 2003, it was computed on the growth of $R \& D$ investments so that only firms with a steadily increasing R\&D budget could benefit fully from it. This tax credit was equal to the half of R\&D growth, and was refundable when the firms paid no taxes. Since 2004, this first tax credit has been completed by a "volume" tax credit, which is a tax credit computed on the amount of R\&D regardless of the R\&D growth. Up to 2005, the firms located in France have a right to a refundable $R \& D$ tax credit equal to the sum of $5 \%$ of their $R \& D$ total amount and to $45 \%$ of their R\&D growth. This policy direction has been extended in 2006 with $10 \%$ for the amount and $40 \%$ for the growth of R\&D expenditures. It is noticeable that this "doublededuction" system now exists in several countries, even though the eligible expenditures differ from one country to another, that the tax credit is not always refundable, and sometimes even taxable (in 9 countries out of 19). Out of 19 OECD countries with a R\&D tax credit, 18 countries apply a volume tax credit (the exception being the USA) and 8 countries apply a growth tax credit. Seven countries apply a "double-deduction" system but with different eligibility rules (Australia, Austria, France, Ireland, Korea, Portugal and Spain).

This tax measures also involve a revenue loss for the State. It is quite difficult to make an international comparison on this variable. For France, averaged over the decade 1994-2003, the $R \& D$ tax credit represents 465 millions Euros a year. The extension to a volume tax credit in 2004 almost doubled this figure, up to 890 millions Euros, and has strongly increased afterwards (1.5 billions Euros in 2006). For 2008, the incremental part of the tax credit has been suppressed and the firms can get 30\% of their total expenditures, with an estimated cost of 4 billions Euros. From the viewpoint of the society, these fiscal deductions are interesting only as far as they really increase the private $R \& D$ investments. The fact that they are taken on public funds (exactly like subsidies, from a public finance viewpoint) calls for the evaluation of this fiscal measures. This first motivation can be reinforced by noticing that, for France, its budget cost has considerably increased and, more generally, that these measures have been extended to larger number of innovating countries. 
The public support to $\mathrm{R} \& \mathrm{D}$ faces the following evaluation problem. Two situations can occur when a tax credit is granted. On the one hand, a firm can integrate the tax credit into its investment decision process and decide to invest more because the deduction exists (i.e. because the price of $R \& D$ is lower with the tax deduction). But, on the other hand, it is possible that a firm does not account for this measure at the investment decision stage, realize afterwards that it has the right to a tax deduction, and asks for it in order to increase its profit. In the former case, the tax measure has the expected effect, while in the latter case it has no effect at all on private R\&D. At the firm level, it is likely that both situations occur, therefore we wish to evaluate the average effect of the measure, in order to know whether the positive effects dominate or not.

An important point when performing the evaluation is to consider a period with no policy change on the R\&D tax credit at all. For this reason, we have restricted our data to 1993-2003, where the $R \& D$ tax credit is computed on the same eligible expenditures, on the growth of $\mathrm{R} \& \mathrm{D}$, with a flat rate of $50 \%$, refundable and not taxable.

\section{Data sources and sample statistics}

An interesting quality of our data set is that it includes true fiscal data at the firm level and not a theoretical computation of firms' rights. It is important since all firms that could apply to the R\&D tax credit do not apply for it in practice. ${ }^{2}$ This feature of the data allows to define a control group and to apply the Rubin methods explained below. This would not be possible without such data since a theoretical computation would allocate a tax credit to all firms with a R\&D growth. Here, among firms with a positive R\&D growth, we can separate firms that get a tax credit from the other firms.

\subsection{Data Sources}

The data comes from three different sources:

- the «enquêtes annuelles d'entreprises » (yearly firm census) provide information on the accounting data (sales, line of business) ;

\footnotetext{
2 This fact is well known at the Ministry of Research and seems do derive from either a bad knowledge of tax deductions or from the erratic nature evolution of growth tax credit. The latter point is consistent with the fact that when the system was extended to the level of R\&D in 2004, some firms entered the system for the first time, while they were performing R\&D for a long time.
} 
- The R\&D survey is collected by the Ministry of Research and provides information at the firm level on $R \& D$, and especially the amount of subsidies from all the ministries. Matching with this data set is important because it allows to correct the R\&D amounts from subsidies and to determine the part of $R \& D$ expenditures that is privately funded;

- The tax credit (CIR) file is collected by the fiscal administration (Direction Générale des Impôts). It is not a survey; it is exhaustive and includes the amount of tax credits granted at the firm level. ${ }^{3}$ It allows to perform a study on the real recipients of the tax credit and to remove the bias related to self-selection.

We use the Frascati (OECD, 2002) definition of R\&D provided by the R\&D survey. Our main performance variable is computed from the private funding of $R \& D$ that we define as the difference between the total R\&D expenditures on the one hand and the sum of all subsidies and tax credit on the other hand. It represents the amount of $R \& D$ actually paid by the firm. We also use data on $R \& D$ personnel in order to examine the robustness of our results.

In order to evaluate the effect of the $R \& D$ tax credit on the growth rates of the private funding of R\&D, we have matched our samples by couple of years over the period 1993-2003. ${ }^{4}$ This convention insures that there remain a large number of firms in the sample. ${ }^{5}$ After these operations, we have 10 samples covering the two-year periods 1994-1993 to 2003-2002. A description of the samples is provided in Table 1. The samples include between 1133 and 1645 firms each year, in all lines of business (including services). Approximately $20 \%$ of the firms benefit from the tax credit alone or from a subsidy only and 7\% benefit from both a subsidy and the tax credit. Over the decade, between $50 \%$ and $60 \%$ of the firms have benefited neither from a subsidy nor from a tax credit. ${ }^{6}$ This point is important because the evaluation relies on a comparison between the recipients and the other firms. In the evaluation literature, the nonrecipients represent the reservoir from which we extract the counterfactuals (Rubin, 2006). The size of this reservoir seems reasonable.

The amounts of public supports to private $R \& D$ are reported in Table 2. As expected, the $R \& D$ subsidies represent the most important amounts, while the $R \& D$ tax credit reach $10 \%$ of the support given to firms. This is related to its incremental nature. However, it is important to

\footnotetext{
${ }^{3}$ Another property of this data set is that it cannot be accessed by the standard procedure in France. The data were made available because there is a law that compels to provide an evaluation of the R\&D tax credit to the Parliament. Access to the data set was decided after a call for offer on the tax credit evaluation among economic research laboratories.

${ }^{4}$ The French firms have a compulsory identification number (the SIREN number) that is available in all our files. This precludes losses due to matching.

${ }^{5}$ A balanced sample over the period would reduce to about 200 firms only, instead of 1500 .

${ }^{6}$ The effect of subsidies has been studied separately in Duguet (2004) with comparable evaluation methods.
} 
keep in mind that these are not the same firms that get these two kinds of public support. The $R \& D$ tax credit, by its fiscal nature, is open to all the firms. It is often argued that the firms do not have the same size depending on they benefit from subsidies or from the tax credit. Figure 1 shows the median size of the recipients depending on the R\&D support that has been granted. Figure 2 present the corresponding average size. We find that while the median size does not differ between the two R\&D mechanisms (a median of about 300 employees), there is a strong difference in the average size. The difference between these two measures comes from the biggest firms that are more present among the subsidy recipients.

The average size is around 500 employees for the tax credit recipient and around 2500 employees for the subsidy recipient. A part of this difference can be attributed to the fact that, over this period, the tax credit is computed on the growth of $R \& D$, and that the higher the level of R\&D the harder it is to make it grow. The comparison of these two figures also confirms that the tax credit is more favorable to the small and medium sized firms.

\section{Figure 1 - Median number of workers depending on the $R \& D$ support mechanism}

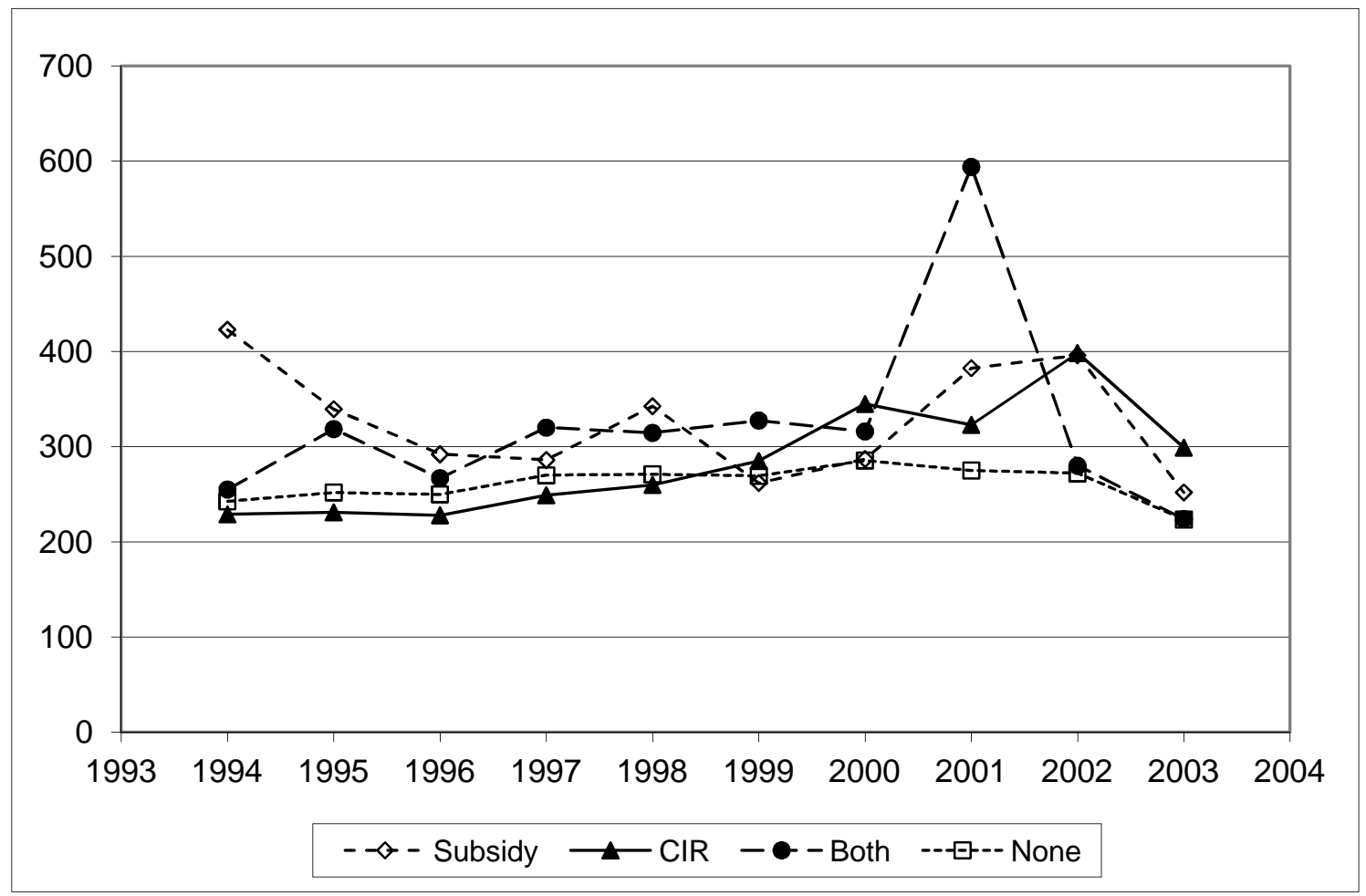


Figure 2 - Average number of workers depending on the $R \& D$ support mechanism

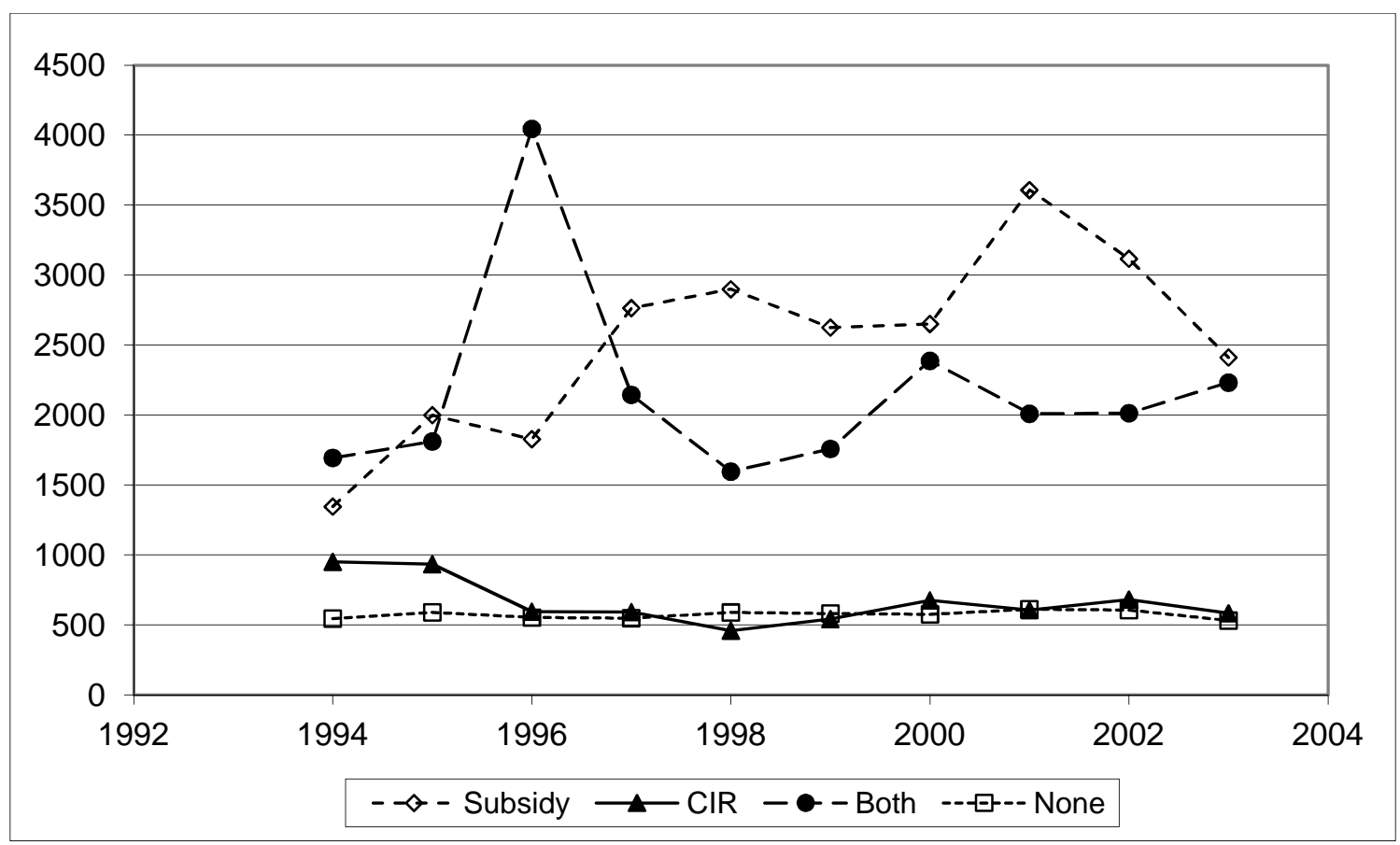

\subsection{Sample Statistics}

In a first step, we will simply perform a comparison of the average growth rate of private $\mathrm{R} \& \mathrm{D}$, in order to assess the descriptive effect of the tax credit. Two types of comparisons can be made. A first comparison, "static", compares the growth rates of the private funding of R\&D depending on the mechanism of the recipients benefit from. A second comparison, "dynamic", examines the same growth rates, depending on the position of the firm inside the tax credit mechanism. Four cases are possible: no tax credit for two years, tax credit during two years, entry into the tax credit and exit from the tax credit mechanism.

The static comparison is presented in Table 3. We find, as expected, that the firms that benefit from the tax credit have the strongest growth rate, partly because it is attributed on that basis (and not fully, because subsidies are deducted from the eligible R\&D). Then come the firms that got both the tax credit and the subsidies. The lowest growth rates have been achieved by the firms that received subsidies alone and the firms that benefited no support.

Our definition of private R\&D excludes both subsidies and the tax credit; therefore a zero growth rate for the private $R \& D$ variable means that the $R \& D$ tax credit would be efficient since 
it involves that the firms have not reduced their private $R \& D$ when they have benefited from the tax credit. In this case, the total $R \& D$ expenditures increases by the amount of tax credit granted. When the effect is positive, there is a multiplier effect, the total $R \& D$ increases by more than the amount of tax credit granted.

However, this first comparison suffers from a serious limitation. It does not allow seeing the effect of the tax deduction since what really matters is how the firms change their behavior when they get the public support. It is why we insist on the dynamic comparison.

The dynamic comparison is performed in Table 4. Here we examine how the growth rate of private $R \& D$ is affected when the firms enter or exit the tax credit mechanism. The variation of the growth rates should be a better proxy for the R\&D tax credit than their levels, even though we are conscious that there remains a selection bias issue. An incentive effect of the measure would involve that the private $R \& D$ does not decrease when a firms enters the mechanism.

The dynamic comparison shows that the firms that enter the tax credit mechanism maintain a significant growth rate of their private $R \& D$ expenditures, which is often above $10 \%$. The firms that enter in or exit from the mechanism do not behave significantly differently from the non recipients. Overall, we find that the firms add exactly the tax credit to their private funding when they enter the mechanism, and add more than the tax credit to their private funding when they stay inside the mechanism.

\subsection{The "naïve" estimator and a critic of sample statistics}

The "naïve" estimator is defined as the difference of means. Its definition comes from the fact that this estimator is the one we should use on experimental data. The result is clear-cut: over all the decade the firms that have benefited from the $R \& D$ tax credit had a stronger growth rate of their R\&D tax credit, except in 2000-2001 which corresponds to the burst of the dot-com bubble.

In practice, $R \& D$ data are not experimental and are affected by selection biases. The firms that get the R\&D tax credit do not have the same characteristics that the firms that get it, and if these unbalanced characteristics are correlated to our performance variable, we should expect a bias when comparing the mean performances of the recipients to the mean performance of the non-recipients. This difference is given in Table 5.

Another critic is related to the type of tax credit that is given: when the tax credit is computed on the growth of $R \& D$, the firms that do not experience a growth of their $R \& D$ are 
not eligible to the tax credit. Therefore comparing the recipients with all the non-recipients is less relevant. Indeed what we would like to measure is the difference the $R \& D$ investment the firms have made and the R\&D investment they would have made without the policy measure. For this, we need a counterfactual computed on the firms that did not benefit from the policy measure but the right counterfactual set seems to be the set of firms that have experienced a growth of their R\&D expenditures and did not ask for the tax credit. ${ }^{7}$ In this paper, we will account for that critic by reporting the results restricted to the firms with a positive growth of $\mathrm{R}_{\mathrm{D}}{ }^{8}$

\section{Methodology}

In order to measure the effect of CIR, one should evaluate the difference between the performance that a firm achieved with the CIR and the performance the same firms would have achieved without this mechanism. The latter quantity is called the counterfactual. There are many ways to estimate a counterfactual. In this paper, we consider two families of methods: standard regression analysis and matching methods. Among the latter we distinguish kernel matching and the weighted estimator.

Let $\mathrm{y}_{1, \mathrm{i}}$ the performance (i.e., the growth rate of private $\mathrm{R} \& \mathrm{D}$ ) of firm $i$ when it benefits from CIR and $\mathrm{y}_{0, i}$ its performance when it does not. The evaluation problem comes from the fact that we cannot observe both quantities at the same time. Either we observe $\mathrm{y}_{1 i}$ when the firm benefits from CIR or we observe $\mathrm{y}_{0 \mathrm{i}}$ when it does not. The observable data is therefore:

$$
\mathrm{y}_{\mathrm{i}}=\left(1-\mathrm{T}_{\mathrm{i}}\right) \mathrm{y}_{0 \mathrm{i}}+\mathrm{T}_{\mathrm{i}} \mathrm{y}_{1 \mathrm{i}} \text { with } \mathrm{T}_{\mathrm{i}}=\left\{\begin{array}{cc}
1 & \text { if firmi benefitsfrom CIR } \\
0 & \text { otherwise }
\end{array}\right.
$$

\subsection{Regression methods}

The simplest method is the naïve estimator that takes the difference of the average performance of recipients and non-recipients. Technically this reduces to perform an OLS regression of the performance on the intercept and a CIR dummy variable (equal to 1 for

\footnotetext{
${ }^{7}$ The lack of information and the fear of a fiscal control are often used to explain such behavior.

${ }^{8}$ This critic also raises an issue when the data comes from the "innovation surveys". The fiscal deduction dummy variable should be merged with R\&D growth data in order to get the right counterfactual when the tax credit is defined on the growth of $R \& D$.
} 
recipients, 0 for the other firms). The OLS coefficient of the CIR dummy variables gives the difference of the mean performances in both groups:

$$
\hat{\mathrm{c}}=\frac{1}{\mathrm{~N}_{1}} \sum_{\mathrm{i} \in \mathrm{I}_{1}} \mathrm{y}_{\mathrm{i}}-\frac{1}{\mathrm{~N}_{0}} \sum_{\mathrm{i} \in \mathrm{I}_{0}} \mathrm{y}_{\mathrm{i}}
$$

where $I_{1}$ is the index set of recipients (number: $N_{1}$ ), and $I_{0}$ the index set of non-recipients (number $\mathrm{N}_{0}$ ).This is the «naive » estimator.

A second method extends the previous model by adding explanative variables $\mathrm{X}_{\mathrm{i}}$ into the previous regression. The model becomes:

$$
y_{i}=a+X_{i} b+c T_{i}+u_{i} .
$$

where $u_{i}$ is the usual disturbance. From this model, we get the two cases:

$T_{i}=0$, with an expected average performance $E\left(y_{i} \mid T_{i}=0\right)=a+X_{i} b$,

and $T_{i}=1$, with an expected average performance $E\left(y_{i} \mid T_{i}=1\right)=a+X_{i} b+c$

This implies that the effect of CIR for the individual $i$ is equal to:

$$
E\left(y_{i} \mid T_{i}=1\right)-E\left(y_{i} \mid T_{i}=0\right)=c .
$$

Compared with the naïve estimator, this regression allows dropping from the evaluation the part that is attributable to the explanative variables $\mathrm{X}_{\mathrm{i}}$.

But, strictly speaking, the previous estimators are not fully consistent with the evaluation problematic. A third regression method is more rigorous. We assume that there are two equations corresponding to each of the potential outcome, so that:

$$
\mathrm{y}_{0 \mathrm{i}}=\mathrm{a}_{0}+\mathrm{X}_{\mathrm{i}} \mathrm{b}_{0}+\mathrm{u}_{0 \mathrm{i}} \text { and } \mathrm{y}_{1 \mathrm{i}}=\mathrm{a}_{1}+\mathrm{X}_{\mathrm{i}} \mathrm{b}_{1}+\mathrm{u}_{1 \mathrm{i}}
$$

And the observable performance is:

$$
y_{i}=\left(1-T_{i}\right) y_{0 i}+T_{i} y_{1 i}=\left(1-T_{i}\right)\left(a_{0}+X_{i} b_{0}+u_{0 i}\right)+T_{i}\left(a_{1}+X_{i} b_{1}+u_{1 i}\right),
$$

After some simplification, we get:

$$
\mathrm{y}_{\mathrm{i}}=\beta_{0}+\mathrm{X}_{\mathrm{i}} \beta_{1}+\mathrm{T}_{\mathrm{i}} \beta_{2}+\mathrm{T}_{\mathrm{i}} \mathrm{X}_{\mathrm{i}} \beta_{3}+\mathrm{u}_{\mathrm{i}}
$$

which implies that one should estimate a model with the cross product of the explanative variables and the CIR dummy. Moreover, if the variables $X_{i}$ are centered, we can show that the 
coefficient of the CIR dummy, $\beta_{2}$, measures the average effect of the tax credit on the performance. ${ }^{9}$

The results produced with the standard regression methods are presented in Table 6. The simple OLS regression method, depending on the year, give results that vary between no effect of the CIR on private R\&D (in 2000-2001) and an important effect of $+11,4 \%$. The effects are globally lower than the ones obtained with the naïve estimator (up to $+12.2 \%$ ), which shows that the explanative variables explain a part of the growth difference between the recipients and the non-recipients. When we include the cross products of the explanative variables with the CIR dummy we get an effect that varies, depending on the year, between 0 and $+10.4 \%$, which shows that the cross product themselves explain a part of the performance differences between the recipients and the other firms.

Overall, the growth rate gap of private $R \& D$ remains in favor of the CIR recipients. The standard OLS regression fails to control for all the differences between these two groups of firms.

Qualitatively, these first results indicate that the effect of CIR would vary between a simple addition effect of CIR and private $R \& D$ (so that the measure is just efficient), and a multiplier effect of CIR on private R\&D (so that firms would increase their R\&D expenditures by more than the amount of the CIR). But it is well known the regression estimators can suffer from selection biases, therefore we turn to the matching methods.

\subsection{Methods that account for the selection bias}

The "evaluation methods" are the most important in this paper since the naive regression methods do not account for the fact that the individuals are not comparable in the recipient and the non recipient groups. We follow the propensity score approach initiated by Rosenbaum and Rubin (1983, 1985) and surveyed in Lee (2005) and Rubin (2006). We aim to estimate the three following parameters:

$c=E\left(y_{1}-y_{0}\right)$, the average effect of the treatment,

\footnotetext{
${ }^{9}$ The structure of this model also implies that the disturbance of the model is heteroskedastic since the disturbance is different depending on $T_{i}=0$ or $T_{i}=1$. We account for this property in our estimations.
} 
$\mathrm{c}_{1}=\mathrm{E}\left(\mathrm{y}_{1}-\mathrm{y}_{0} \mid \mathrm{T}=1\right)$, the average effect of the treatment on the treated;

$\mathrm{c}_{0}=\mathrm{E}\left(\mathrm{y}_{1}-\mathrm{y}_{0} \mid \mathrm{T}=0\right)$, the average effect of the treatment on the not treated.

These three quantities are related by the following relationship:

$$
\mathrm{c}=\mathrm{c}_{1} \operatorname{Pr}[\mathrm{T}=1]+\mathrm{c}_{0} \operatorname{Pr}[\mathrm{T}=0] .
$$

Following Rubin (1974) and Rosenbaum and Rubin (1983, 1985), we make the conditional independence assumption:

$$
\left(\mathrm{y}_{0}, \mathrm{y}_{1}\right) \perp \mathrm{T}\left|\mathrm{X} \Rightarrow\left(\mathrm{y}_{0}, \mathrm{y}_{1}\right) \perp \mathrm{T}\right| \mathrm{P}(\mathrm{T}=1 \mid \mathrm{X})
$$

The intuition of this result is the following: if two firms have the same probability to get the CIR, and the first firm does have it while the other has not, then the allocation of CIR can be considered as random between these two firms, and we can use the second firm as a counterfactual for the first firm.

Estimation of the average effect on the treated $c_{l}$. We consider the CIR recipients and, for each of them, we estimate the performance they would have had without the CIR. In practice, we compare the performance of the CIR recipient with the average performance of the non recipients that have the same probability to get the CIR. In this paper, we use the method of Heckman, Ichimura and Todd (1998). The average performance that the CIR recipients ( $i \in I_{1}$ ) would have had without the CIR is estimated by:

$$
\hat{\mathrm{y}}_{0, \mathrm{i}}=\sum_{\mathrm{j} \in \mathrm{I}_{0}} \frac{\mathrm{K}\left[\left(\hat{\mathrm{p}}_{\mathrm{j}}-\hat{\mathrm{p}}_{\mathrm{i}}\right) / \mathrm{h}\right] \times \mathrm{y}_{\mathrm{j}}}{\sum_{\mathrm{j} \in \mathrm{I}_{0}} \mathrm{~K}\left[\left(\hat{\mathrm{p}}_{\mathrm{j}}-\hat{\mathrm{p}}_{\mathrm{i}}\right) / \mathrm{h}\right]}, \quad \mathrm{i} \in \mathrm{I}_{1}
$$

Where $\mathrm{K}($.$) is a Gaussian kernel, \mathrm{h}$ the rule-of-thumb window and $\hat{\mathrm{p}}_{\mathrm{i}}$ the estimated probability to get the CIR for the firm i. Symmetrically, the performance that the non recipients ( $i \in I_{0}$ ) would have had if they had benefited from CIR is estimated by:

$$
\hat{\mathrm{y}}_{1, \mathrm{i}}=\sum_{\mathrm{j} \in \mathrm{I}_{1}} \frac{\mathrm{K}\left[\left(\hat{\mathrm{p}}_{\mathrm{j}}-\hat{\mathrm{p}}_{\mathrm{i}}\right) / \mathrm{h}\right] \times \mathrm{y}_{\mathrm{j}}}{\sum_{\mathrm{j} \in \mathrm{I}_{1}} \mathrm{~K}\left[\left(\hat{\mathrm{p}}_{\mathrm{j}}-\hat{\mathrm{p}}_{\mathrm{i}}\right) / \mathrm{h}\right]}, \mathrm{i} \in \mathrm{I}_{0},
$$

Therefore, the average effect of CIR on the treated is defined as: 
$\hat{\mathrm{c}}_{1}=\frac{1}{\mathrm{~N}_{1}} \sum_{\mathrm{i} \in \mathrm{I}_{1}}\left\{\mathrm{y}_{1, \mathrm{i}}-\hat{\mathrm{y}}_{0, \mathrm{i}}\right\}$

the average effect on the not treated by:

$\hat{\mathrm{c}}_{0}=\frac{1}{\mathrm{~N}_{0}} \sum_{\mathrm{i} \in \mathrm{I}_{0}}\left\{\hat{\mathrm{y}}_{1, \mathrm{i}}-\mathrm{y}_{0, \mathrm{i}}\right\}$,

and the average effect on the whole population by:

$$
\hat{\mathrm{c}}=\frac{1}{\mathrm{~N}_{0}+\mathrm{N}_{1}}\left(\sum_{\mathrm{i} \in \mathrm{I}_{0}}\left\{\hat{\mathrm{y}}_{1, \mathrm{i}}-\mathrm{y}_{0, \mathrm{i}}\right\}+\sum_{\mathrm{i} \in \mathrm{I}_{1}}\left\{\mathrm{y}_{1, \mathrm{i}}-\hat{\mathrm{y}}_{0, \mathrm{i}}\right\}\right) .
$$

The standard errors of these statistics are complicated to write, so that we use the bootstrap method with 1500 repetitions (including the Probit step for $\hat{\mathrm{p}}_{\mathrm{i}}$ ).

The weighting approach, surveyed in Lee (2005), uses the same assumptions than kernel matching, but merely expresses the non observable sample moments by their observable counterparts, and replaces them by the corresponding empirical moments. We get the following results:

Effect of the treatment on the not treated:

$$
\hat{\mathrm{c}}_{0}=\frac{1}{\mathrm{~N}} \sum_{\mathrm{i}=1}^{\mathrm{N}}\left(\frac{\mathrm{N}_{0}}{\mathrm{~N}}\right)^{-1} \mathrm{y}_{\mathrm{i}}\left(\frac{\mathrm{T}_{\mathrm{i}}}{\hat{\mathrm{p}}_{\mathrm{i}}}-1\right)
$$

Effect of the treatment on the treated:

$$
c_{1}=\frac{1}{N} \sum_{i=1}^{N^{c}}\left(\frac{N_{1}}{N}\right)^{-1} y_{i}\left(\frac{T_{i}-\hat{p}_{i}}{1-\hat{p}_{i}}\right)
$$

Effect of the treatment on the whole population:

$$
\hat{c}=\frac{1}{N} \sum_{i=1}^{N} y_{i}\left(\frac{T_{i}-\hat{p}_{i}}{\hat{p}_{i}\left(1-\hat{p}_{i}\right)}\right)
$$

Where $\hat{\mathrm{p}}_{\mathrm{i}}$ is the estimated value of the propensity score for the individual $i$, $\mathrm{N}$ the number of firms in the common support, $\mathrm{N}_{0}$ the number of not treated firms in the common support and 
$\mathrm{N}_{1}$ the corresponding number of treated firms. The variances of theses estimators must be corrected to account for the estimation of the Probit model in the first step, but it can be determined by the delta method. The details are given in appendix.

It is possible that the regression methods give inconsistent estimators because the CIR is not distributed at random to the firms. As for all policy measures, there are attribution procedures that determine who is eligible. This creates differences between the sample of recipients and the other firms and, provided that these differences are correlated with the performance measure, the OLS regression estimates can be inconsistent. It is therefore desirable to "balance" the covariates so that the firms are comparable. In practice, this creates an incentive to match each recipient firm to the non-recipient firms that share the same value of the observable covariates. There are many matching methods in the literature. In this paper, we follow the approach by Rosenbaum and Rubin $(1983,1985)$, and match our firms on the propensity score, which is simply the probability to get the CIR.

The intuition of this theoretical result is the following: if two firms have the same probability to get the CIR, that the first one got it and the second one did not, everything happens as if the CIR was allocated at random among these two firms. Therefore, for each recipient, we look for all the non-recipients that have the same probability to get the CIR and then we compute the difference between the performance of the recipient and the average performance of the other firms (the counterfactual). These operations are performed for all the recipients, and the effect of CIR is given by the average of all these differences (i.e., the "effect on the treated").

The same method can be used to determine the potential effect of CIR on the firms that did not get it. One just needs to match each non-recipient firm with the recipients that have the same probability to get the CIR.

The only problem that remains is therefore to estimate the probability to get the CIR. We estimate a Probit model and use the predicted probabilities. ${ }^{10}$ Notice that the replacement of the true probabilities by the estimated probabilities implies to modify the way to compute the Student statistics. We have used the bootstrapped Student statistics to account for it. The last point is to make sure that the probabilities between the recipients and the non-recipients have a

\footnotetext{
${ }^{10}$ We have performed Vuong test of the Probit model against the Logit model. We find that the models are equivalent for all the couples of years, except for 2000-2001 were the Probit model outperforms the Logit model. Therefore, we kept the Probit model for all our regressions.
} 
sufficient overlap so that we compare firms with similar probabilities. We have used the common support of the predicted probabilities to fix this problem. ${ }^{11}$

Last, notice that this method is related to the instrumental variable method in the following way. The estimation relies on the estimated probabilities to get the CIR, and these estimated probabilities depend on instrumental variables only (mostly lagged variables in our application).

In our application, we have applied three different estimation methods on the common support of the CIR probabilities:

- the OLS regression methods, so as to see what is the influence of changing the data set by dropping the extreme probabilities;

- The kernel matching method (Rubin approach). It allows for distinguishing the effect on the treated from the effect of the non-treated;

- The weighted estimator (or "moment estimator"), which is equivalent to kernel matching but much faster to compute since it replaces the bootstrap method by the delta method (see the appendix).

The Rubin methodology implies to drop some observations from the sample when the probabilities take extreme values (close to 0 or to 1 ). The estimations are performed on the common support of the estimated CIR probabilities. Therefore, if we wish to compare this method with the OLS regression methods, we should do it on the same sample, on the common support, so as to make sure that the differences comes from the method itself and not from a sample difference only.

Table 7 presents the OLS regression methods on the common support. We do not find important differences with the regressions over the whole sample, so that the difference of samples cannot be advocated to explain difference of results among the standard and Rubin methods.

\subsection{Empirical strategy}

A problem specific to the tax credit systems computed on the growth of R\&D comes from the fact that our performance variable is correlated to the attribution conditions. Therefore we cannot use the standard method without caution. There are two ways to tackle that problem:

${ }^{11}$ In practice, we define the probability support by the first and 99th percentiles in order to suppress the influence of outliers. 
- First, one can restrict the analysis to the firms that have a positive growth rate of their $R \& D$. This is because only these firms are eligible and it should improve on the quality of the matching. This is only possible however because some firms that have the right to the tax credit do not ask for it.

- Second, one can use another variable than the growth rate of $R \& D$. We need a variable that is both related to the R\&D effort and not to a "short-run" effect caused by the CIR. We use the growth rate of the (full-time) number of researchers. Indeed, the researchers are the ones that hold the knowledge of the firm, so that the firms should be reluctant to hire or lay-off researchers just to benefit from a short-run tax deduction. The number of researchers is an essential input of the innovation process so that is should be a good indicator of the "real" innovation policy of the firm. Keeping the researchers inside the firm avoids the dissemination of knowledge to competitors and many studies show that the firms care about this issue (Levin et al., 1987, Duguet and Kabla, 1998).

We have also tried instrumental variables methods (not reported) but their results were similar to those of the standard regression methods, and often gave a stronger effect of CIR on the growth of private $R \& D$.

In order to measure the effect of CIR on private $R \& D$, we use the following empirical strategy:

- Estimators over the whole sample;

- Estimators restricted to the firms with a positive growth rate of private R\&D;

- Estimators on the growth rate of the number of researchers.

\subsection{Multipliers computation}

There are two ways to compute the tax credit multipliers in the literature: first, one divides the tax credit amount by the amount of R\&D the firms would have made without it (impact of the tax credit on $R \& D$ ); second, one divides the incremental amount of $R \& D$ performed under the tax credit by the amount of tax credit distributed (additional number of Euros of R\&D for one Euro of tax credit distributed). This section writes the explicit relationships between our estimates and these two kinds of multipliers. We need the following notations:

- $\mathrm{c}_{1}$ denotes the effect on the treated; 
- $R_{0}$ is the amount of $R \& D$ that would have been invested without the CIR and $R_{1}$ is the amount of R\&D that would have been invested under the tax credit.

- We have the following relationship between these quantities:

$$
\mathrm{c}_{1}=\frac{\mathrm{R}_{1}-\mathrm{R}_{0}}{\mathrm{R}_{0}} \Leftrightarrow \mathrm{R}_{1}=\left(1+\mathrm{c}_{1}\right) \mathrm{R}_{0}
$$

- "R" denotes the private $R \& D$ expenditures.

- The R\&D subsidies have been subtracted from all our measures of R\&D (private and total) so that we really measure the net effect of the tax credit on R\&D.

\subsubsection{R\&D expenditures multipliers}

All our multipliers are computed on the subset of CIR recipient firms, since there is no direct effect on the others by definition. This is a significant difference with aggregated data where total $R \& D$ usually refers to country $R \& D$ and therefore includes the non recipients.

\section{Private $R \& D$ expenditures multiplier}

Consider first the private $R \& D$ multiplier. With the tax credit, a firm invests $R_{1}$ while without it, the same firm would have invested $R_{0}=R_{1} /\left(1+c_{1}\right)$, therefore the private $R \& D$ multiplier is equal to:

$$
\mathrm{m}_{\mathrm{P}}=\frac{\mathrm{R}_{1}}{\left(\frac{\mathrm{R}_{1}}{1+\mathrm{c}_{1}}\right)}=1+\mathrm{c}_{1},
$$

\section{Total $R \& D$ expenditures multiplier}

Consider now the total $R \& D$ multiplier. The total $R \& D$ of a recipient firm is equal to $\mathrm{R}_{1}+\mathrm{CIR}$ under the tax credit, while it is $\mathrm{R}_{0}=\mathrm{R}_{1} /\left(1+\mathrm{c}_{1}\right)$ without it. The total $\mathrm{R} \& \mathrm{D}$ multiplier is therefore equal to:

$$
\mathrm{m}_{\mathrm{T}}=\frac{\mathrm{R}_{1}+\mathrm{CIR}}{\left(\frac{\mathrm{R}_{1}}{1+\mathrm{c}_{1}}\right)}=\left(1+\mathrm{c}_{1}\right)\left(1+\mathrm{CIR} / \mathrm{R}_{1}\right),
$$

In this paper, we present the mean value of this multiplier over the sample, which gives: 


$$
\overline{\mathrm{m}}_{\mathrm{T}}=\left(1+\mathrm{c}_{1}\right)\left(1+\overline{\mathrm{CIR} / \mathrm{R}_{1}}\right)
$$

\subsubsection{Tax credit multipliers}

Private $R \& D$ tax credit multiplier

The variation of private $R \& D$ induces by CIR is equal to:

$$
\mathrm{R}_{1}-\mathrm{R}_{0}=\mathrm{R}_{1}-\frac{\mathrm{R}_{1}}{1+\mathrm{c}_{1}}=\frac{\mathrm{c}_{1}}{1+\mathrm{c}_{1}} \mathrm{R}_{1}
$$

so that the multiplier equals:

$$
\mathrm{M}_{\mathrm{P}}=\frac{\mathrm{R}_{1}-\mathrm{R}_{0}}{\mathrm{CIR}}=\frac{\mathrm{c}_{1}}{1+\mathrm{c}_{1}} \frac{\mathrm{R}_{1}}{\mathrm{CIR}} .
$$

We estimate it at the mean point of the sample by:

$$
\mathrm{M}_{\mathrm{P}}=\frac{\mathrm{c}_{1}}{1+\mathrm{c}_{1}} \overline{\left(\frac{\mathrm{R}_{1}}{\mathrm{CIR}}\right)},
$$

\section{Total R\&D tax credit multiplier}

The variation of total R\&D induced by the CIR is equal to:

$$
\mathrm{R}_{1}+\mathrm{CIR}-\mathrm{R}_{0}=\frac{\mathrm{c}_{1}}{1+\mathrm{c}_{1}} \mathrm{R}_{1}+\mathrm{CIR}
$$

So that the multiplier equals:

$$
\mathrm{M}_{\mathrm{T}}=\frac{\mathrm{CIR}+\mathrm{R}_{1}-\mathrm{R}_{0}}{\mathrm{CIR}}=1+\mathrm{M}_{\mathrm{P}} .
$$

\section{Results}

In a first subsection, we report the determinants of the probability to get the CIR and, in a second subsection, we comment on the evaluation. 


\subsection{The probability to get CIR}

The main determinant of CIR is its lagged value (Table 8). This result illustrates the importance of the dynamic comparison reported in Table 4. But other variables also influence the probability to get the CIR: the $\mathrm{R} \& \mathrm{D} /$ sales ratio increases the probability to get the tax credit and the benefit from R\&D subsidies reduces it. In the latter case, there could be a mechanical effect coming from the fact that the R\&D subsidies are not eligible to the tax credit. Finally, we also find that some lines of business use more the tax credit on some years, but we do not find time persistence on this point. This could come from the fact that the tax credit is more open to firms than R\&D subsidies.

A second interesting result is the small number of significant explanative variables in the Probit regressions. This also suggests that entry into the tax credit mechanism is more open than for R\&D subsidies (Duguet, 2004). In order to test the robustness of this result, we have also run the Probit regressions without the lagged tax credit variable (not reported). We find that the most important determinant of the probability to get the tax credit is the $R \& D / s a l e s$ ratio. Therefore the $R \& D$ tax credit is directed toward the firms that allocate the biggest part of their sales to R\&D. This selection of recipients certainly explains for a good part, the results of the evaluations that follow.

\subsection{The effect of CIR}

The kernel matching and weighting methods provide similar results (Table 9). We comment mostly on the weighting estimators because they provide smaller standard errors.

The estimation on the recipients represents the evaluation strictly speaking (the « effect on the treated »): we seek to estimate the effect of the tax credit on the firms that have indeed benefited from it, and not on the whole sample of R\&D performers. The basic results show a multiplier effect on 6 years out of 10, and an addition effect for the 4 remaining years.

The estimation on the sample of firms that have not benefited from the tax credit represents the effect the CIR would have had if it has been extended to more R\&D firms. We find that the potential effect of the tax credit on this subsample of firms is weaker than on the recipients since we find a multiplier effect for 1 year and an addition effect on 9 years. However, we do not find a (firm-level) « crowding-out » effect. 
However, these first estimates must be taken with caution. Since the tax credit is incremental, we could think that the standard evaluation procedure overestimates the effect of $\mathrm{CIR}$ on the growth rate of private $\mathrm{R} \& \mathrm{D}$. Therefore, we also present the estimation, with the same methodology, on the subsample of firms that had a positive growth rate of their private $R \& D$ and, despite of this, did not ask for CIR. The results, reported in Table 10, should represent a lower bound of the effect of the tax credit. This «lower bound shows an addition effect for all the 10 years. According to it, the firms would add the tax credit to their private funding so that there would be no « crowding out » effect.

It is possible to convert the results reported in Tables 10 and 11 into multipliers of the total $R \& D$ expenditures. Since the study is performed over ten couple of years, we comment on the average value (Tables 11 and 12).

The estimations based on the total sample (Table 10) indicate that the CIR would have increased private $R \& D$ by $7.9 \%$ (Table 11 , multiplier 1.079 ) and total $R \& D$ (with the CIR) by $11.2 \%$. The effect would thus be important on the recipients. When we restrict the analysis to the firms that have increased their private $R \& D$ (Table 11), the corresponding effects would be between $0 \%$ (unit multiplier), a simple addition effect, and the total R\&D would have increased by $3.2 \%$ only.

A common practice expresses the multipliers as a function of CIR itself. Over the whole sample (Table 10) we find that 1 Euro of CIR would generate 2.33 Euros of private R\&D that is $3.33(=1+2.33)$ Euros of total R\&D (Table 12). When we restrict the analysis to the positive growth rates (Table 12) we find a more pessimistic result that 1 Euro of CIR would not generate any Euro of private R\&D, so that 1 Euro of CIR would generate 1 Euro of total R\&D. However, since our evaluation is a short-run one (one year), this figure is in fact rather high.

\subsection{Testing the robustness of our estimators: the number of researchers}

A basic reason that may reduce the trust that we have in the previous estimates is the incremental nature of the $R \& D$ tax credit. We reply to this critic by proposing the following robustness test. The R\&D performers may have an interest in asking for tax deductions even when they do not need it, but the same R\&D performers have no interest in letting their knowledge leak out for free to their competitors. Therefore, if they do not use the R\&D tax credit for research, we should see no R\&D personnel variations. We use growth rate of the 
number of researchers, in equivalent full time, since they are the holders of the firm's knowledge. The results are reported in Table 13.

We find that, over the whole population, the $R \& D$ tax credit is always associated to positive growth of the number of researchers, varying between $7.5 \%$ and $12.6 \%$ depending on the couple

of years. If we restrict our analysis to the firms that had a positive growth rate of their private $\mathrm{R} \& \mathrm{D}$, we find a positive effect 5 years out of 10 (from $6.6 \%$ to $10 \%$ ) and no effect on five years. These results suggest that the $R \& D$ performers would use the incremental $R \& D$ tax credit in order to invest in $\mathrm{R} \& \mathrm{D}$.

\section{Conclusion}

We find that the incremental $R \& D$ tax credit benefits to a different population of firms than the ones that benefit from subsidies. The tax credit recipients have a smaller size and a high R\&D to Sales ratio. This confirms the view that the tax measures favor equality among the innovative firms.

Applying methods that control for selection biases, we find that the incremental R\&D tax incentive is effective, since it is associated both to a growth of the private funding of $R \& D$ (or adds to it), and to a growth of the number of researchers on most years.

However, the results in this study apply to the incremental tax credit only, which is based on the growth of the privately funded R\&D. It does not seem to be extendable to other form of tax mechanism, since they apply to a different population of firms (larger, especially). New research should be done in order to evaluate the reforms that have been taken place in France since 2004. 


\section{References}

Aerts C. and D. Czarnitzki (2004). «Using innovation survey data to evaluate R\&D policy : the case of Belgium”. Working paper, ZEW N04-55. ftp://ftp.zew.de/pub/zew-docs/dp/dp0455.pdf

Berger P. (1993). «Explicit and implicit effects of the R\&D tax credit". Journal of Accounting Research, 31(2), 131-171.

Busom I. (1999). «An empirical evaluation of R\&D subsidies ». University of California, Burch Working Paper, $\mathrm{N}^{\circ}$ B99-05.

Crépon B. and N. Iung (1999). Innovation, emploi et performances. INSEE, DESE, Working paper G9904.

Czarnitzki D., P. Hanel and J.M. Rosa (2004). "Evaluating the impact of R\&D tax credit on innovation: A microeconometric study on Canadian firms". Working paper, $\mathrm{N}^{\circ}$ 04-77. ftp://ftp.zew.de/pub/zew-docs/dp/dp0477.pdf

D'Aspremont, C. and Jacquemin, A. (1988). "Cooperative and non cooperative R\&D in duopoly with spillovers". American Economic Review, 78, 1133-1137.

Duguet E. (2004). "Are R\&D subsidies a substitute or a complement to privately funded R\&D? An econometric analysis at the firm level”, Revue d'Economie Politique, 14(2), 263-292.

Duguet E. and I. Kabla (1998). "Appropriation strategy and the motivations to use the patent system in France: an econometric analysis at the firm level". Annales d'Economie et de Statistique, n49-50, 290327.

Efron B. and J. Tibshirani (1993). An introduction to the bootstrap. Monographs on Statistics and Applied Probability n57. Chapman \& Hall. ISBN 0-412-04231-2.

Gouriéroux C. (2000). Econometrics of Qualitative Dependent Variables. Cambridge University Press (ISBN 0521589851).

Guellec D. and B. Van Pottelsberghe (2000). "The impact of public R\&D expenditure on business R\&D”. Working paper, OECD, STI, N²000-4.

Hall B. H. and J. Van Reenen (2000). "How effective are fiscal incentives for R\&D? A review of the evidence”. Research Policy, vol. 29, 449-469.

Heckman J. and J. Hotz (1988). Choosing among alternative nonexperimental methods for estimating the impact of social programs : the case of manpower training. Journal of the American Statistical Society, vol. 84, n408, 862-874.

Heckman J., H. Ichimura and P. Todd (1997). Matching as an econometric evaluation estimator : evidence from evaluating a job training programme. Review of Economic Studies, vol. 64, 605-654.

Hujer H. and D. Radic (2005). «Evaluating the impact of subsidies on innovation activities in Germany ». Working paper, ZEW, N05-43. ftp://ftp.zew.de/pub/zew-docs/dp/dp0543.pdf

Hussinger K. (2003). "R\&D and subsidies at the firm level: An application of parametric and semiparametric two-step selection model". Working paper, ZEW, N03-63. ftp://ftp.zew.de/pub/zewdocs/dp/dp0363.pdf

Kaiser U. (2004). «Private R\&D and public R\&D subsidies: Microeconometric evidence from Denmark”. Working paper, Center for Economic and Business Research, N²004-19.

Kamien M., Muller E. and I. Zang (1992). Research joint ventures and R\&D cartels. The American Economic Review, 82(5), 1293-1992.

Klette T.J. and J. Møen (1998). "R\&D investment responses to R\&D subsidies : a theoretical analysis and a microeconometric study. Working paper, NBER Summer Institute.

Kleinknecht A. ed. (1996). Determinants of innovation: The message from new indicators. Palgrave. ISBN 0333648005. 
Kleinknecth A. and P. Mohnen eds. (2002). Innovation and firm performance: Econometric explorations of survey data. Palgrave. ISBN 0333961099.

Lach S. (2002). Do R\&D subsidies stimulate or displace private R\&D ? Evidence from Israël. The Journal of Industrial Economics, vol. L(4), 369-390.

Lee Myoung-Jae (2005). Micro-Econometrics for Policy, Program and Treatment Effects. Oxford University Press. ISBN 0199267685.

Levin, R., A. Klevorick, R. Nelson and S. Winter (1987). Appropriating the returns from industrial R\&D. Brookings Papers on Economic Activity, 783-820.

Mairesse J. and B. Mulkay (2004). «Une évaluation du crédit d'impôt recherche en France : 19801997 ». Working paper, CREST, N²004-43.

Mansfield E. (1986). "The R\&D tax credit and other policy issues". The American Economic Review, 76(2), 190-194.

OECD (2002). Frascati manual: Proposed standard practice for Surveys on Research and Experimental Development.

OCDE (2003). "Tax incentives for research and development : trends and issues". Working paper, OECD, STI.

Rosenbaum P. and D. Rubin (1983). The central role of the propensity score in observational studies for causal effects. Biometrika; vol. 70, 41-55.

Rosenbaum P. and D. Rubin (1985). Constructing a control group using multivariate matched sampling methods that incorporate the propensity score. The American Statistician; vol. 39, $\mathrm{n}^{\circ} 1,33-38$.

Rubin, D. (1974). Estimating causal effects of treatments in randomized and non-randomized studies, Journal of Educational Psychology, 66, pp. 688-701.

Rubin D. (1997). Estimating causal effects from large data sets using propensity scores. Annals of Internal Medicine, Part 2, $\mathrm{n}^{\circ}$ 127, 757-763.

Rubin D. (2006). Matched sampling for causal effects. Cambridge University Press, ISBN 9780521674362.

Wallsten S. (2000). The effect of governement-industry R\&D programs on private R\&D : the case of Small Business Innovation Research program. RAND Journal of Economics, vol. 31(1), 82-100.

Warda J. (2006). "Tax treatment of business investments in intellectual assets: an international comparison”. Working paper, OECD, STI, N²006-4. 


\section{Appendix: Estimation of the variance of the weighting estimators}

Slightly extending the analysis in Crépon and Iung (1999), we write the three estimators under the following form:

$$
\hat{\theta}=\frac{1}{N} \sum_{i=1}^{N} y_{i} g_{i}(\hat{b})
$$

where $\hat{b}$ is the estimated parameter from the Probit model. Using the delta method, we can estimate the variance of our estimate by:

$$
\hat{\mathrm{V}}(\hat{\theta})=\frac{1}{\mathrm{~N}} \sum_{\mathrm{i}=1}^{\mathrm{N}}\left(\hat{\varphi}_{\mathrm{i}}-\overline{\hat{\varphi}}\right)^{2}
$$

with

$$
\hat{\varphi}_{i}=y_{i} g_{i}(\hat{b})+\frac{1}{N} \sum_{i=1}^{N}\left[y_{i} \frac{\partial g_{i}}{\partial b^{\prime}}(\hat{b})\right] J_{1}(\hat{b})^{-1} \sqrt{N} s_{i}(\hat{b})
$$

where

$$
J_{1}(b)=E\left[-\frac{\partial^{2} \ln f}{\partial b \partial b^{\prime}}(T \mid X, b)\right], s_{i}(b)=\frac{\partial \ln f\left(T_{i} \mid X_{i}, b\right)}{\partial b},
$$

and

$$
\operatorname{lnf}\left(\mathrm{T}_{\mathrm{i}} \mid \mathrm{X}_{\mathrm{i}}, \mathrm{b}\right)=\mathrm{T}_{\mathrm{i}} \ln \Phi\left(\mathrm{X}_{\mathrm{i}} \mathrm{b}\right)+\left(1-\mathrm{T}_{\mathrm{i}}\right) \ln \left(1-\Phi\left(\mathrm{X}_{\mathrm{i}} \mathrm{b}\right)\right)
$$

Notice that these formulas are valid for any binary model estimated by the maximum likelihood method, provided that one replaces $\Phi\left(X_{i} b\right) \Phi$ by $1-F\left(-X_{i} b\right)$ where $F($.$) is the cdf$ of the disturbance of the new model (or by $\mathrm{F}\left(\mathrm{X}_{\mathrm{i}} \mathrm{b}\right)$ if the distribution is symmetric). 
Table 1: Public Support to Private R\&D

\begin{tabular}{cccccc}
\hline \hline Year & $\begin{array}{c}\text { Subsidy } \\
\text { Alone }\end{array}$ & $\begin{array}{c}\text { Tax Credit } \\
\text { Alone }\end{array}$ & $\begin{array}{c}\text { Both } \\
\text { Subsidy } \\
\text { and Tax } \\
\text { Credit }\end{array}$ & $\begin{array}{c}\text { No Public } \\
\text { Support }\end{array}$ & Sample size \\
\hline 1994 & $21,1 \%$ & $19,5 \%$ & $8,6 \%$ & $50,9 \%$ & $1553(100 \%)$ \\
1995 & $19,1 \%$ & $18,4 \%$ & $7,4 \%$ & $55,1 \%$ & $1645(100 \%)$ \\
1996 & $19,5 \%$ & $16,7 \%$ & $7,0 \%$ & $56,9 \%$ & $1639(100 \%)$ \\
1997 & $18,8 \%$ & $17,3 \%$ & $6,1 \%$ & $57,9 \%$ & $1570(100 \%)$ \\
1998 & $20,1 \%$ & $17,2 \%$ & $6,3 \%$ & $56,3 \%$ & $1482(100 \%)$ \\
1999 & $20,1 \%$ & $17,2 \%$ & $7,1 \%$ & $55,5 \%$ & $1491(100 \%)$ \\
2000 & $20,0 \%$ & $17,6 \%$ & $8,5 \%$ & $53,9 \%$ & $1213(100 \%)$ \\
2001 & $16,8 \%$ & $19,1 \%$ & $7,9 \%$ & $56,2 \%$ & $1133(100 \%)$ \\
2002 & $17,0 \%$ & $18,3 \%$ & $6,5 \%$ & $58,1 \%$ & $1299(100 \%)$ \\
2003 & $17,6 \%$ & $16,7 \%$ & $5,8 \%$ & $59,8 \%$ & $1542(100 \%)$ \\
\hline \hline
\end{tabular}

Table 2: Amount of Public Support to R\&D

\begin{tabular}{cccc}
\hline \hline Year & Subsidies & Tax Credit & Total* \\
\hline 1994 & $94,8 \%$ & $5,2 \%$ & $2292(100 \%)$ \\
1995 & $92,5 \%$ & $7,5 \%$ & $2045(100 \%)$ \\
1996 & $92,0 \%$ & $8,0 \%$ & $1542(100 \%)$ \\
1997 & $90,2 \%$ & $9,8 \%$ & $1253(100 \%)$ \\
1998 & $88,4 \%$ & $11,6 \%$ & $1207(100 \%)$ \\
1999 & $91,1 \%$ & $8,9 \%$ & $2083(100 \%)$ \\
2000 & $93,1 \%$ & $6,9 \%$ & $1727(100 \%)$ \\
2001 & $87,7 \%$ & $12,3 \%$ & $1573(100 \%)$ \\
2002 & $90,5 \%$ & $9,5 \%$ & $1901(100 \%)$ \\
2003 & $90,3 \%$ & $9,7 \%$ & $1194(100 \%)$ \\
\hline \hline
\end{tabular}

Notes $*$ In millions Euros, computed on the sample 
Table 3: Static comparison of the growth rates of the private funding of $R \& D$

* Significant at the 5\% level

\begin{tabular}{clcccc}
\hline \hline & & Subsidy & $\begin{array}{c}\text { Tax Credit } \\
\text { (CIR) }\end{array}$ & Both & None \\
\hline \multirow{2}{*}{$1993-1994$} & Average & $-11,5 \%$ & $-6,3 \%$ & $0,9 \%$ & $-18,3 \%$ \\
& Student & $4,99^{*}$ & $3,07^{*}$ & 0,29 & $12,71^{*}$ \\
\multirow{2}{*}{$1994-1995$} & Average & $3,2 \%$ & $11,6 \%$ & $9,1 \%$ & $2,9 \%$ \\
& Student & 1,72 & $6,46^{*}$ & $3,31^{*}$ & $2,91^{*}$ \\
$1995-1996$ & Average & $0,6 \%$ & $6,8 \%$ & $3,3 \%$ & $1,1 \%$ \\
& Student & 0,31 & $3,54^{*}$ & 1,15 & 1,05 \\
\multirow{2}{*}{$1996-1997$} & Average & $-1,6 \%$ & $9,7 \%$ & $7,2 \%$ & $2,3 \%$ \\
& Student & 0,89 & $5,19^{*}$ & $2,31^{*}$ & $2,34 *$ \\
$1997-1998$ & Average & $1,6 \%$ & $10,3 \%$ & $2,4 \%$ & $1,0 \%$ \\
& Student & 0,83 & $5,53^{*}$ & 0,65 & 0,93 \\
$1998-1999$ & Average & $-2,1 \%$ & $10,5 \%$ & $8,6 \%$ & $0,2 \%$ \\
& Student & 0,84 & $4,21^{*}$ & 1,83 & 0,13 \\
\multirow{2}{*}{$1999-2000$} & Average & $-0,3 \%$ & $6,9 \%$ & $3,1 \%$ & $-1,1 \%$ \\
& Student & 0,12 & $2,84^{*}$ & 0,68 & 0,74 \\
$2000-2001$ & Average & $6,5 \%$ & $6,6 \%$ & $8,1 \%$ & $3,9 \%$ \\
& Student & $2,15 *$ & $2,58^{*}$ & $2,18 *$ & $2,11 *$ \\
$2001-2002$ & Average & $0,0 \%$ & $11,5 \%$ & $1,0 \%$ & $-1,4 \%$ \\
& Student & 0,00 & $5,24 *$ & 0,22 & 0,92 \\
$2002-2003$ & Average & $-2,6 \%$ & $8,1 \%$ & $-1,2 \%$ & $-1,8 \%$ \\
& Student & 0,88 & $3,28^{*}$ & 0,32 & 1,32 \\
\hline \hline
\end{tabular}


Table 4: Dynamic comparison of the growth rates of private $R \& D$

** Significant at the 5\% level. * Significant at the $10 \%$ level.

\begin{tabular}{|c|c|c|c|c|c|c|c|c|}
\hline & \multicolumn{4}{|c|}{$\begin{array}{c}\text { (Tax credit in } \mathrm{t}-1 \text {, Tax credit in } \mathrm{t} \text { ) } \\
\text { Growth rates }\end{array}$} & \multicolumn{2}{|c|}{ 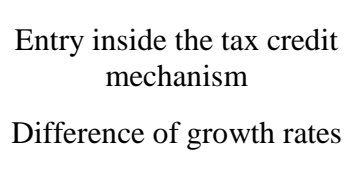 } & \multicolumn{2}{|c|}{$\begin{array}{l}\text { Exit from the tax credit } \\
\text { mechanism } \\
\text { Difference of growth } \\
\text { rates }\end{array}$} \\
\hline & $\begin{array}{l}\text { (Out, } \\
\text { Out) }\end{array}$ & (Out, In) & (In, Out) & (In, In) & $\begin{array}{l}\text { (Out,In)- } \\
\text { (Out,Out) }\end{array}$ & Student & $\begin{array}{l}\text { (In,In)- } \\
\text { (In,Out) }\end{array}$ & Student \\
\hline$(1993,1994)$ & $-0,162$ & $-0,131$ & $-0,168$ & $-0,015$ & 0,032 & 0,77 & 0,154 & $4,27 * *$ \\
\hline$(1994,1995)$ & 0,028 & 0,079 & 0,042 & 0,119 & 0,051 & 1,56 & 0,077 & $2,43 * *$ \\
\hline$(1995,1996)$ & 0,010 & 0,054 & 0,006 & 0,059 & 0,044 & 1,16 & 0,054 & 1,60 \\
\hline$(1996,1997)$ & 0,010 & 0,026 & 0,040 & 0,118 & 0,016 & 0,52 & 0,078 & $2,40 * *$ \\
\hline$(1997,1998)$ & 0,009 & 0,032 & 0,032 & 0,103 & 0,023 & 0,64 & 0,070 & $1,82 *$ \\
\hline$(1998,1999)$ & $-0,004$ & $-0,004$ & $-0,006$ & 0,164 & 0,000 & 0,01 & 0,170 & $4,32 * *$ \\
\hline$(1999,2000)$ & $-0,015$ & $-0,012$ & 0,040 & 0,088 & 0,004 & 0,10 & 0,048 & 1,03 \\
\hline$(2000,2001)$ & 0,047 & 0,003 & 0,030 & 0,098 & $-0,043$ & 1,12 & 0,068 & 1,39 \\
\hline$(2001,2002)$ & $-0,012$ & 0,010 & $-0,001$ & 0,122 & 0,022 & 0,55 & 0,123 & $3,08 * *$ \\
\hline$(2002,2003)$ & $-0,018$ & $-0,006$ & $-0,036$ & 0,085 & 0,012 & 0,31 & 0,120 & $2,65 * *$ \\
\hline
\end{tabular}

Table 5: Global comparison of the average growth rates of the private funding of $R \& D$

* Significant at the 5\% level.

\begin{tabular}{ccccc}
\hline \hline & $\begin{array}{c}\text { Tax credit } \\
\text { recipient }\end{array}$ & $\begin{array}{c}\text { Non } \\
\text { recipient }\end{array}$ & Difference & Student \\
\hline $1993-1994$ & $-0,041$ & $-0,163$ & 0,122 & $5,80^{*}$ \\
$1994-1995$ & 0,108 & 0,030 & 0,079 & $4,52^{*}$ \\
$1995-1996$ & 0,058 & 0,010 & 0,048 & $2,60^{*}$ \\
$1996-1997$ & 0,090 & 0,013 & 0,077 & $4,22^{*}$ \\
$1997-1998$ & 0,081 & 0,012 & 0,070 & $3,59^{*}$ \\
$1998-1999$ & 0,099 & $-0,004$ & 0,104 & $4,10^{*}$ \\
$1999-2000$ & 0,056 & $-0,009$ & 0,065 & $2,53^{*}$ \\
$2000-2001$ & 0,070 & 0,045 & 0,025 & 0,97 \\
$2001-2002$ & 0,087 & $-0,011$ & 0,098 & $4,07^{*}$ \\
$2002-2003$ & 0,057 & $-0,020$ & 0,077 & $3,14^{*}$ \\
\hline \hline
\end{tabular}




\section{Table 6: Regression methods}

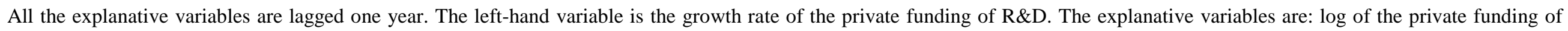

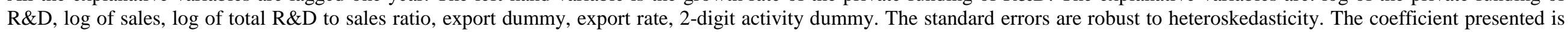
the one of the CIR dummy. ** Significant at the 5\% level. * Significant at the $10 \%$ level.

\begin{tabular}{|c|c|c|c|c|c|c|c|c|c|c|c|c|c|c|c|c|c|c|c|c|}
\hline & \multicolumn{2}{|c|}{ 1994-1993 } & \multicolumn{2}{|c|}{ 1995-1994 } & \multicolumn{2}{|c|}{ 1996-1995 } & \multicolumn{2}{|c|}{$1997-1996$} & \multicolumn{2}{|c|}{$1998-1997$} & \multicolumn{2}{|c|}{ 1999-1998 } & \multicolumn{2}{|c|}{ 2000-1999 } & \multicolumn{2}{|c|}{$2001-2000$} & \multicolumn{2}{|c|}{ 2002-2001 } & \multicolumn{2}{|c|}{ 2003-2002 } \\
\hline & Coeff & Student & Coeff & Student & Coeff & Student & Coeff & Student & Coeff & Student & Coeff & Student & Coeff & Student & Coeff & Student & Coeff & Student & Coeff & Student \\
\hline $\begin{array}{l}\text { Naive } \\
\text { estimator } \\
\text { (Table 5) }\end{array}$ & 0,122 & $5,80^{* *}$ & 0,079 & $4,53 * *$ & 0,048 & $2,60 * *$ & $\mathbf{0 , 0 7 7}$ & $4,23 * *$ & $\mathbf{0 , 0 7 0}$ & $3,59 * *$ & 0,104 & $4,11 * *$ & 0,065 & $2,53 * *$ & 0,025 & 0,97 & $\mathbf{0 , 0 9 8}$ & $4,07 * *$ & $\mathbf{0 , 0 7 7}$ & $3,14 * *$ \\
\hline OLS & 0,114 & $5,39 * *$ & $\mathbf{0 , 0 8 6}$ & $5,00 * *$ & $\mathbf{0 , 0 5 1}$ & $2,75^{* *}$ & 0,079 & $4,42 * *$ & 0,074 & $3,83 * *$ & $\mathbf{0 , 1 0 1}$ & $4,04 * *$ & $\mathbf{0 , 0 5 8}$ & $2,25 * *$ & $\mathbf{0 , 0 3 0}$ & 1,17 & $\mathbf{0 , 1 0 0}$ & $4,24 * *$ & 0,068 & $2,82 * *$ \\
\hline $\begin{array}{l}\text { OLS with } \\
\text { cross products }\end{array}$ & 0,104 & $4,73 * *$ & $\mathbf{0 , 0 8 4}$ & $4,71 * *$ & 0,048 & $2,53 * *$ & 0,066 & $3,67 * *$ & $\mathbf{0 , 0 7 5}$ & $3,81 * *$ & $\mathbf{0 , 0 8 8}$ & $3,28 * *$ & $\mathbf{0 , 0 5 4}$ & $2,00 * *$ & $\mathbf{0 , 0 3 9}$ & 1,55 & 0,105 & $4,39 * *$ & 0,068 & $2,69 * *$ \\
\hline
\end{tabular}

Table 7: Regression methods on the common support of the probabilities to get the CIR

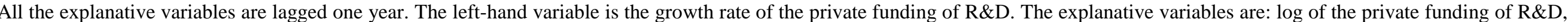

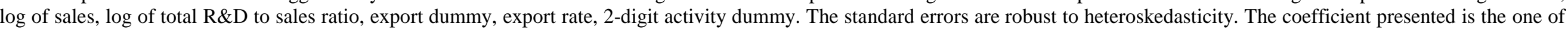
the CIR dummy. ** Significant at the $5 \%$ level. * Significant at the $10 \%$ level.

\begin{tabular}{|c|c|c|c|c|c|c|c|c|c|c|c|c|c|c|c|c|c|c|c|c|}
\hline & \multicolumn{2}{|c|}{ 1994-1993 } & \multicolumn{2}{|c|}{$1995-1994$} & \multicolumn{2}{|c|}{ 1996-1995 } & \multicolumn{2}{|c|}{$1997-1996$} & \multicolumn{2}{|c|}{ 1998-1997 } & \multicolumn{2}{|c|}{$1999-1998$} & \multicolumn{2}{|c|}{ 2000-1999 } & \multicolumn{2}{|c|}{$2001-2000$} & \multicolumn{2}{|c|}{ 2002-2001 } & \multicolumn{2}{|c|}{ 2003-2002 } \\
\hline & Coeff & Student & Coeff & Student & Coeff & Student & Coeff & Student & Coeff & Student & Coeff & Student & Coeff & Student & Coeff & Student & Coeff & Student & Coeff & Student \\
\hline Naïve estimator & 0,123 & $5,57 * *$ & 0,092 & $4,93 * *$ & 0,050 & $2,56 * *$ & 0,084 & $4,37 * *$ & 0,065 & $3,25 * *$ & 0,106 & $3,97 * *$ & 0,071 & $2,69 * *$ & $\mathbf{0 , 0 5 3}$ & $1,93 *$ & 0,112 & $4,61 * *$ & 0,086 & $3,31 * *$ \\
\hline OLS & 0,110 & $5,05 * *$ & 0,089 & $4,90 * *$ & 0,052 & $2,68 * *$ & 0,078 & $4,09 * *$ & 0,063 & $3,20 * *$ & 0,099 & $3,77 * *$ & 0,063 & $2,43 * *$ & 0,040 & 1,48 & 0,113 & $4,73 * *$ & $\mathbf{0 , 0 7 3}$ & $2,89 * *$ \\
\hline $\begin{array}{l}\text { OLS with cross } \\
\text { products }\end{array}$ & 0,100 & $4,46 * *$ & 0,085 & $4,59 * *$ & 0,047 & $2,43 * *$ & 0,067 & $3,50 * *$ & 0,065 & $3,35^{* *}$ & 0,086 & $3,14 * *$ & 0,064 & $2,50 * *$ & 0,040 & 1,58 & 0,112 & $4,70 * *$ & 0,065 & $2,47 * *$ \\
\hline
\end{tabular}


Table 8: Probit estimates of the probability to benefit from CIR

Left-hand variable: CIR benefit dummy (yes/no). All the right-hand variables are lagged one year. Maximum likelihood estimates of the Probit model.

\begin{tabular}{|c|c|c|c|c|c|c|c|c|c|c|c|c|c|c|c|c|c|c|c|c|}
\hline & \multicolumn{2}{|c|}{ 1994-1993 } & \multicolumn{2}{|c|}{ 1994-1993 } & \multicolumn{2}{|c|}{ 1995-1994 } & \multicolumn{2}{|c|}{ 1995-1994 } & \multicolumn{2}{|c|}{ 1996-1995 } & \multicolumn{2}{|c|}{ 1996-1995 } & \multicolumn{2}{|c|}{ 1997-1996 } & \multicolumn{2}{|c|}{ 1997-1996 } & \multicolumn{2}{|c|}{ 1998-1997 } & \multicolumn{2}{|c|}{ 1998-1997 } \\
\hline & Coeff & Student & Coeff & Student & Coeff & Student & Coeff & Student & Coeff & Student & Coeff & Student & Coeff & Student & Coeff & Student & Coeff & Student & Coeff & Student \\
\hline Intercept & $-0,80$ & 2,39 & $-0,86$ & 5,89 & $-1,08$ & 3,10 & $-1,00$ & 7,56 & $-1,06$ & 3,11 & $-1,27$ & 22,43 & $-0,97$ & 2,68 & $-1,29$ & 23,52 & $-1,41$ & 3,66 & $-0,99$ & 7,17 \\
\hline Lagged CIR dummy & 1,59 & 20,24 & 1,59 & 20,39 & 1,70 & 21,44 & 1,70 & 21,68 & 1,63 & 20,14 & 1,62 & 20,64 & 1,64 & 19,63 & 1,64 & 20,06 & 1,72 & 19,79 & 1,71 & 19,95 \\
\hline $\log ($ Sales $)$ & $-0,01$ & 0,30 & & & 0,03 & 1,05 & & & $-0,01$ & 0,18 & & & $-0,01$ & 0,28 & & & 0,04 & 1,39 & & \\
\hline $\log$ (total RD/sales) & 0,06 & 1,32 & 0,07 & 1,98 & 0,11 & 2,76 & 0,09 & 2,84 & 0,01 & 0,36 & & & 0,05 & 1,20 & & & 0,13 & 2,96 & 0,10 & 2,81 \\
\hline RD subsidy dummy & 0,14 & 1,41 & & & 0,06 & 0,57 & & & 0,03 & 0,26 & & & 0,00 & 0,04 & & & $-0,05$ & 0,43 & & \\
\hline RD subsidy/Total RD & $-0,76$ & 1,97 & $-0,52$ & 1,56 & $-0,93$ & 2,18 & $-0,80$ & 2,16 & $-0,24$ & 0,64 & & & $-0,68$ & 1,52 & $-0,55$ & 1,46 & 0,20 & 0,48 & & \\
\hline Export dummy & 0,05 & 0,33 & & & $-0,26$ & 1,62 & & & $-0,07$ & 0,44 & & & 0,12 & 0,69 & & & 0,04 & 0,23 & & \\
\hline Exports/Sales & $-0,58$ & 3,16 & $-0,58$ & 3,43 & $-0,06$ & 0,33 & & & 0,18 & 1,03 & & & 0,09 & 0,54 & & & $-0,15$ & 0,88 & & \\
\hline Food industry & $-0,10$ & 0,45 & & & 0,06 & 0,26 & & & $-0,07$ & 0,31 & & & 0,20 & 0,95 & 0,33 & 1,96 & 0,09 & 0,36 & & \\
\hline Consumer goods & $-0,02$ & 0,12 & & & 0,06 & 0,37 & & & $-0,02$ & 0,12 & & & $-0,28$ & 1,55 & & & 0,31 & 1,66 & 0,24 & 2,08 \\
\hline Equipment goods & $-0,09$ & 0,57 & & & 0,14 & 0,84 & & & $-0,16$ & 1,03 & & & $-0,15$ & 0,92 & & & 0,06 & 0,34 & & \\
\hline Intermediate goods & $-0,15$ & 0,99 & & & 0,23 & 1,48 & 0,15 & 1,76 & $-0,29$ & 1,98 & $-0,19$ & 2,25 & $-0,26$ & 1,67 & & & 0,14 & 0,86 & & \\
\hline Services & $-0,36$ & 1,83 & $-0,27$ & 1,87 & $-0,09$ & 0,47 & & & $-0,17$ & 0,91 & & & $-0,62$ & 2,82 & $-0,39$ & 2,41 & 0,04 & 0,18 & & \\
\hline \multirow[t]{3}{*}{ Other (incl.. car industry) } & Réf & & Réf & & Réf & & Réf & & Réf & & Réf & & Réf & & Réf & & Réf & & Réf & \\
\hline & \multicolumn{2}{|c|}{ 1999-1998 } & \multicolumn{2}{|c|}{ 1999-1998 } & \multicolumn{2}{|c|}{$2000-1999$} & \multicolumn{2}{|c|}{ 2000-1999 } & \multicolumn{2}{|c|}{$2001-2000$} & \multicolumn{2}{|c|}{$2001-2000$} & \multicolumn{2}{|c|}{$2002-2001$} & \multicolumn{2}{|c|}{ 2002-2001 } & \multicolumn{2}{|c|}{ 2003-2002 } & \multicolumn{2}{|c|}{$2003-2002$} \\
\hline & Coeff & Student & Coeff & Student & Coeff & Student & Coeff & Student & Coeff & Student & Coeff & Student & Coeff & Student & Coeff & Student & Coeff & Student & Coeff & Student \\
\hline Intercept & $-0,86$ & 2,41 & $-1,11$ & 3,83 & $-1,79$ & 4,22 & $-1,64$ & 5,26 & $-1,60$ & 3,71 & $-1,73$ & 5,36 & $-1,74$ & 4,46 & $-1,83$ & 6,12 & $-1,30$ & 3,90 & $-1,32$ & 23,97 \\
\hline Lagged CIR dummy & 1,39 & 16,59 & 1,40 & 17,00 & 1,65 & 17,82 & 1,65 & 17,92 & 1,70 & 17,74 & 1,69 & 17,75 & 1,57 & 17,61 & 1,56 & 17,94 & 1,62 & 19,31 & 1,63 & 19,60 \\
\hline $\log ($ Sales $)$ & 0,04 & 1,51 & 0,04 & 1,81 & 0,05 & 1,56 & 0,05 & 1,64 & 0,09 & 2,78 & 0,08 & 2,76 & 0,05 & 1,61 & 0,05 & 1,98 & 0,03 & 1,06 & & \\
\hline $\log$ (total RD/sales) & 0,04 & 0,94 & & & 0,06 & 1,30 & 0,06 & 1,46 & 0,13 & 2,88 & 0,13 & 3,14 & $-0,02$ & 0,44 & & & 0,07 & 1,89 & & \\
\hline RD subsidy dummy & $-0,02$ & 0,17 & & & 0,03 & 0,30 & & & 0,12 & 0,99 & & & $-0,11$ & 0,93 & & & $-0,08$ & 0,67 & & \\
\hline RD subsidy/Total RD & 0,15 & 0,42 & & & 0,11 & 0,30 & & & $-0,61$ & 1,48 & & & 0,23 & 0,51 & & & $-0,27$ & 0,61 & & \\
\hline Export dummy & $-0,58$ & 3,19 & $-0,60$ & 3,45 & 0,28 & 1,21 & & & $-0,32$ & 1,36 & & & 0,04 & 0,19 & & & $-0,03$ & 0,16 & & \\
\hline Exports/Sales & 0,41 & 2,54 & 0,36 & 2,28 & 0,27 & 1,43 & 0,29 & 1,69 & 0,31 & 1,62 & 0,25 & 1,45 & $-0,01$ & 0,08 & & & $-0,06$ & 0,38 & & \\
\hline Food industry & 0,04 & 0,19 & & & $-0,06$ & 0,23 & & & 0,21 & 0,77 & & & $-0,29$ & 1,17 & & & 0,20 & 0,94 & & \\
\hline Consumer goods & $-0,12$ & 0,69 & & & $-0,24$ & 1,22 & & & 0,08 & 0,39 & & & $-0,05$ & 0,28 & & & 0,19 & 1,22 & 0,22 & 1,88 \\
\hline Equipment goods & $-0,22$ & 1,39 & & & $-0,17$ & 0,94 & & & 0,12 & 0,63 & & & $-0,05$ & 0,32 & & & 0,05 & 0,37 & & \\
\hline Intermediate goods & $-0,38$ & 2,56 & $-0,25$ & 3,02 & $-0,09$ & 0,51 & & & $-0,05$ & 0,29 & $-0,16$ & 1,59 & $-0,20$ & 1,25 & & & $-0,07$ & 0,47 & & \\
\hline Services & $-0,14$ & 0,69 & & & 0,07 & 0,31 & & & 0,06 & 0,25 & & & $-0,25$ & 1,19 & & & $-0,35$ & 1,81 & $-0,35$ & 2,21 \\
\hline Other (incl... car industry) & Réf & & Réf & & Réf & & Réf & & Réf & & Réf & & Réf & & Réf & & Réf & & Réf & \\
\hline
\end{tabular}




\section{Table 9: Evaluation estimators à la Rubin on the whole sample}

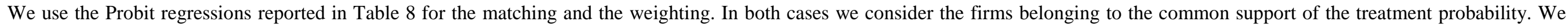
report the effect of the CIR on the growth rate of the private funding of R\&D. ** significant at $5 \%$. *significant at $10 \%$.

\begin{tabular}{|c|c|c|c|c|c|c|c|c|c|c|c|c|c|c|c|c|c|c|c|c|}
\hline & \multicolumn{2}{|c|}{ 1994-1993 } & \multicolumn{2}{|c|}{ 1995-1994 } & \multicolumn{2}{|c|}{ 1996-1995 } & \multicolumn{2}{|c|}{ 1997-1996 } & \multicolumn{2}{|c|}{ 1998-1997 } & \multicolumn{2}{|c|}{ 1999-1998 } & \multicolumn{2}{|c|}{ 2000-1999 } & \multicolumn{2}{|c|}{$2001-2000$} & \multicolumn{2}{|c|}{$2002-2001$} & \multicolumn{2}{|c|}{ 2003-2002 } \\
\hline & Coeff & Student & Coeff & Student & Coeff & Student & Coeff & Student & Coeff & Student & Coeff & Student & Coeff & Student & Coeff & Student & Coeff & Student & Coeff & Student \\
\hline & \multicolumn{20}{|c|}{ Weighting estimators } \\
\hline $\begin{array}{l}\text { Average effect on } \\
\text { the population }\end{array}$ & 0,069 & $2,40 * *$ & 0,078 & $2,93 * *$ & 0,049 & 1,58 & 0,040 & 1,57 & $\mathbf{0 , 0 5 5}$ & $1,79 *$ & $\mathbf{0 , 0 3 5}$ & 0,91 & 0,044 & 1,36 & 0,008 & 0,23 & 0,066 & $2,04 * *$ & 0,054 & $1,75^{*}$ \\
\hline $\begin{array}{l}\text { Average effect on } \\
\text { the not treated }\end{array}$ & 0,043 & 1,30 & 0,074 & $2,41 * *$ & 0,048 & 1,36 & $\mathbf{0 , 0 3 4}$ & 1,17 & 0,054 & 1,55 & 0,016 & 0,36 & 0,047 & 1,29 & $-0,009$ & 0,22 & $\mathbf{0 , 0 5 3}$ & 1,44 & 0,042 & 1,24 \\
\hline $\begin{array}{l}\text { Average effect on } \\
\text { the treated }\end{array}$ & 0,140 & $4,60 * *$ & 0,087 & $3,35^{* *}$ & 0,051 & 1,88 & 0,062 & $2,46 * *$ & 0,056 & $1,90^{*}$ & 0,099 & $3,17 * *$ & $\mathbf{0 , 0 3 6}$ & 1,01 & $\mathbf{0 , 0 5 0}$ & 1,34 & 0,105 & $3,28 * *$ & 0,097 & $2,93 * *$ \\
\hline
\end{tabular}

Kernel matching estimators

(The asymptotic Student $t$ are computed by the bootstrap with 1500 repetitions, including the Probit step)

\begin{tabular}{|c|c|c|c|c|c|c|c|c|c|c|c|c|c|c|c|c|c|c|c|c|}
\hline $\begin{array}{l}\text { Average effect on } \\
\text { the population }\end{array}$ & $\mathbf{0 , 0 8 0}$ & $2,58 * *$ & $\mathbf{0 , 0 7 0}$ & $2,69 * *$ & 0,051 & 1,61 & $\mathbf{0 , 0 3 7}$ & 1,41 & 0,039 & 1,32 & 0,041 & 1,13 & $\mathbf{0 , 0 2 0}$ & 0,57 & $\mathbf{0 , 0 1 3}$ & 0,37 & $\mathbf{0 , 0 6 3}$ & $1,93 *$ & 0,048 & 1,53 \\
\hline $\begin{array}{l}\text { Average effect on } \\
\text { the not treated }\end{array}$ & 0,061 & $1,71^{*}$ & 0,064 & $2,14 * *$ & 0,049 & 1,37 & $\mathbf{0 , 0 2 8}$ & 0,96 & $\mathbf{0 , 0 3 5}$ & 1,05 & $\mathbf{0 , 0 2 4}$ & 0,60 & 0,017 & 0,44 & $-0,002$ & 0,05 & 0,051 & 1,38 & $\mathbf{0 , 0 3 4}$ & 0,97 \\
\hline $\begin{array}{l}\text { Average effect on } \\
\text { the treated }\end{array}$ & $\mathbf{0 , 1 2 9}$ & $4,14 * *$ & $\mathbf{0 , 0 8 7}$ & $3,32 * *$ & $\mathbf{0 , 0 5 7}$ & $2,03 * *$ & $\mathbf{0 , 0 6 8}$ & $2,56 * *$ & $\mathbf{0 , 0 5 4}$ & 1,70 & 0,096 & $3,02 * *$ & $\mathbf{0 , 0 2 8}$ & 0,75 & $\mathbf{0 , 0 5 0}$ & 1,29 & 0,101 & $3,04 * *$ & $\mathbf{0 , 1 0 0}$ & $2,97 * *$ \\
\hline
\end{tabular}




\section{Table 10: Evaluation estimators à la Rubin on the positive growth rates}

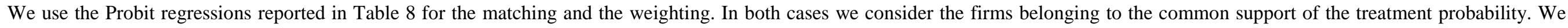
report the effect of the CIR on the growth rate of the private funding of R\&D.. ** significant at $5 \%$. *significant at $10 \%$.

\begin{tabular}{|c|c|c|c|c|c|c|c|c|c|c|c|c|c|c|c|c|c|c|c|c|}
\hline & \multicolumn{2}{|c|}{ 1994-1993 } & \multicolumn{2}{|c|}{ 1995-1994 } & \multicolumn{2}{|c|}{ 1996-1995 } & \multicolumn{2}{|c|}{ 1997-1996 } & \multicolumn{2}{|c|}{ 1998-1997 } & \multicolumn{2}{|c|}{ 1999-1998 } & \multicolumn{2}{|c|}{$2000-1999$} & \multicolumn{2}{|c|}{$2001-2000$} & \multicolumn{2}{|c|}{$2002-2001$} & \multicolumn{2}{|c|}{$2003-2002$} \\
\hline & Coeff & Student & Coeff & Student & Coeff & Student & Coeff & Student & Coeff & Student & Coeff & Student & Coeff & Student & Coeff & Student & Coeff & Student & Coeff & Student \\
\hline & \multicolumn{20}{|c|}{ Weighting estimators } \\
\hline $\begin{array}{l}\text { Average effect on } \\
\text { the population }\end{array}$ & $-0,032$ & 1,40 & 0,075 & $2,25 * *$ & 0,014 & 0,64 & 0,048 & $1,71 *$ & $\mathbf{0 , 0 3 3}$ & 0,92 & $\mathbf{0 , 0 8 9}$ & $2,11 * *$ & $-0,043$ & 1,60 & $-0,034$ & 1,32 & 0,004 & 0,14 & $-0,028$ & 1,17 \\
\hline $\begin{array}{l}\text { Average effect on } \\
\text { the not treated }\end{array}$ & $-0,043$ & 1,47 & 0,103 & $2,38 * *$ & 0,025 & 0,93 & $\mathbf{0 , 0 5 2}$ & 1,54 & $\mathbf{0 , 0 5 7}$ & 1,29 & 0,104 & $1,98 * *$ & $-0,047$ & 1,56 & $-0,050$ & $1,68^{*}$ & 0,010 & 0,30 & $-0,039$ & 1,48 \\
\hline $\begin{array}{l}\text { Average effect on } \\
\text { the treated }\end{array}$ & $-0,014$ & 0,62 & 0,016 & 0,56 & $-0,012$ & 0,59 & $\mathbf{0 , 0 3 6}$ & 1,46 & $-0,026$ & 0,90 & $\mathbf{0 , 0 5 5}$ & 1,64 & $-\mathbf{- 0 , 0 3 3}$ & 1,06 & 0,001 & 0,05 & $-0,011$ & 0,36 & 0,004 & 0,14 \\
\hline
\end{tabular}

Kernel matching estimators

(The asymptotic Student $t$ are computed by the bootstrap with 1500 repetitions, including the Probit step)

\begin{tabular}{|c|c|c|c|c|c|c|c|c|c|c|c|c|c|c|c|c|c|c|c|c|}
\hline $\begin{array}{l}\text { Average effect on } \\
\text { the population }\end{array}$ & $-0,043$ & $1,90 *$ & 0,042 & 1,46 & $\mathbf{0 , 0 2 0}$ & 0,85 & $\mathbf{0 , 0 3 2}$ & 1,28 & $\mathbf{0 , 0 2 6}$ & 0,85 & 0,065 & $1,87^{*}$ & $-0,011$ & 0,35 & $-0,040$ & 1,47 & 0,015 & 0,52 & $-\mathbf{0 , 0 1 3}$ & 0,44 \\
\hline $\begin{array}{l}\text { Average effect on } \\
\text { the not treated }\end{array}$ & $-0,054$ & $2,02 * *$ & $\mathbf{0 , 0 5 3}$ & 1,51 & $\mathbf{0 , 0 3 3}$ & 1,20 & $\mathbf{0 , 0 3 2}$ & 1,09 & $\mathbf{0 , 0 4 7}$ & 1,34 & 0,067 & $1,67 *$ & $-0,011$ & 0,30 & $-0,052$ & $1,76^{*}$ & 0,010 & 0,30 & $-\mathbf{0 , 0 1 3}$ & 0,42 \\
\hline $\begin{array}{l}\text { Average effect on } \\
\text { the treated }\end{array}$ & $-0,026$ & 1,02 & 0,020 & 0,67 & $-0,012$ & 0,52 & $\mathbf{0 , 0 3 3}$ & 1,27 & $-0,028$ & 0,88 & 0,060 & $1,79^{*}$ & $-0,011$ & 0,33 & $-0,013$ & 0,37 & 0,025 & 0,92 & $-0,011$ & 0,29 \\
\hline
\end{tabular}


Table 11: Multipliers according to the private $R \& D$ expenditures Average estimation over the period 1994-2003*

\begin{tabular}{|c|c|c|c|c|c|c|}
\hline & $\begin{array}{c}\text { Private } \\
\text { R\&D }\end{array}$ & $\begin{array}{c}\text { Lower } \\
\text { bound } \\
95 \%\end{array}$ & $\begin{array}{c}\text { Upper } \\
\text { bound } \\
95 \%\end{array}$ & $\begin{array}{c}\text { Total R\&D } \\
\text { expenditures }\end{array}$ & $\begin{array}{c}\text { Lower } \\
\text { bound } \\
95 \%\end{array}$ & $\begin{array}{c}\text { Upper bound } \\
95 \%\end{array}$ \\
\hline \multicolumn{7}{|c|}{ Over the whole sample (Table 10): } \\
\hline Weighting estimator & 1,079 & 1,060 & 1,097 & 1,112 & 1,093 & 1,131 \\
\hline Kernel matching estimator & 1,078 & 1,059 & 1,098 & 1,112 & 1,092 & 1,131 \\
\hline \multicolumn{7}{|c|}{ On the positive growth rates (Table 11 ) : } \\
\hline Weighting estimator & 1,000 & 0,983 & 1,017 & 1,032 & 1,015 & 1,050 \\
\hline Kernel matching estimator & 1,003 & 0,985 & 1,022 & 1,035 & 1,017 & 1,054 \\
\hline
\end{tabular}

*We use the weighted average of the effects over the period 1994-2003, where the (optimal) weight is equal to the inverse of each estimator's variance.

Table 12: Multipliers according to the amount of tax credit distributed Average estimation over the period 1994-2003*

\begin{tabular}{|c|c|c|c|c|c|c|}
\hline & $\begin{array}{c}\text { Private } \\
\text { R\&D }\end{array}$ & $\begin{array}{c}\text { Lower } \\
\text { bound } \\
95 \%\end{array}$ & $\begin{array}{c}\text { Upper } \\
\text { bound } \\
95 \%\end{array}$ & $\begin{array}{c}\text { Total } \mathbf{R} \& D \\
\text { expenditures }\end{array}$ & $\begin{array}{c}\text { Lower } \\
\text { bound } \\
95 \%\end{array}$ & $\begin{array}{c}\text { Upper bound } \\
95 \%\end{array}$ \\
\hline \multicolumn{7}{|c|}{ Over the whole sample (Table 10): } \\
\hline Weighting estimator & 2,327 & 1,774 & 2,881 & 3,327 & 2,774 & 3,881 \\
\hline Kernel matching estimator & 2,315 & 1,743 & 2,887 & 3,315 & 2,743 & 3,887 \\
\hline \multicolumn{7}{|c|}{ On the positive growth rates (Table 11 ) : } \\
\hline Weighting estimator & 0,011 & $-0,503$ & 0,525 & 1,011 & 0,497 & 1,525 \\
\hline Kernel matching estimator & 0,119 & $-0,436$ & 0,675 & 1,119 & 0,564 & 1,675 \\
\hline
\end{tabular}

*We use the weighted average of the effects over the period 1994-2003, where the (optimal) weight is equal to the inverse of each estimator's variance. 


\section{Table 13: Effect of the $R \& D$ tax credit on the growth rate of the number of researchers}

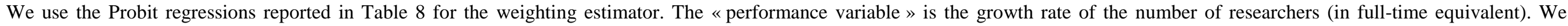
consider the firms belonging to the common support of the treatment probability. ** significant at $5 \%$. *significant at $10 \%$.

\begin{tabular}{|c|c|c|c|c|c|c|c|c|c|c|c|c|c|c|c|c|c|c|c|c|}
\hline & \multicolumn{2}{|c|}{$1994-1993$} & \multicolumn{2}{|c|}{ 1995-1994 } & \multicolumn{2}{|c|}{ 1996-1995 } & \multicolumn{2}{|c|}{ 1997-1996 } & \multicolumn{2}{|c|}{ 1998-1997 } & \multicolumn{2}{|c|}{ 1999-1998 } & \multicolumn{2}{|c|}{ 2000-1999 } & \multicolumn{2}{|c|}{ 2001-2000 } & \multicolumn{2}{|c|}{ 2002-2001 } & \multicolumn{2}{|c|}{ 2003-2002 } \\
\hline & Coeff & Student & Coeff & Student & Coeff & Student & Coeff & Student & Coeff & Student & Coeff & Student & Coeff & Student & Coeff & Student & Coeff & Student & Coeff & Student \\
\hline & \multicolumn{20}{|c|}{ Over the whole sample } \\
\hline $\begin{array}{l}\text { Average effect on } \\
\text { the population }\end{array}$ & $0,105 * *$ & 3,36 & $0,116 * *$ & 4,13 & $0,088^{* * *}$ & 2,81 & 0,118 ** & 3,54 & 0,061 & 1,87 & $0,112^{* * *}$ & 3,13 & $0,119 * *$ & 2,63 & $0,082 * *$ & 2,71 & $0,099 * *$ & 2,90 & $0,102 * *$ & 3,00 \\
\hline $\begin{array}{l}\text { Average effect on } \\
\text { the not treated }\end{array}$ & $0,099 * *$ & 2,75 & $0,115 * *$ & 3,61 & $0,078^{* *}$ & 2,19 & $0,117 * *$ & 3,08 & 0,045 & 1,24 & $0,107 * *$ & 2,71 & $0,134 * *$ & 2,52 & $0,082 * *$ & 2,45 & $0,096 * *$ & 2,56 & $0,100^{* *}$ & 2,68 \\
\hline \multirow[t]{2}{*}{$\begin{array}{l}\text { Average effect on } \\
\text { the treated }\end{array}$} & $0,120 * *$ & 3,78 & $0,121 * *$ & 3,84 & $0,122^{* * *}$ & 3,79 & $0,123 * *$ & 3,81 & $0,109 * *$ & 3,08 & $0,126^{* * *}$ & 3,83 & $0,075^{* *}$ & 2,00 & $\mathbf{0 , 0 8 4} * *$ & 2,20 & $0,108 * *$ & 2,89 & $0,109 * *$ & 2,97 \\
\hline & \multicolumn{20}{|c|}{ On the positive growth rates of private $R \& D$} \\
\hline $\begin{array}{l}\text { Average effect on } \\
\text { the population }\end{array}$ & $\mathbf{0 , 0 0 8}$ & 0,19 & $0,098 * *$ & 2,3 & $0,069 *$ & 1,73 & $\mathbf{0 , 0 7 5 *}$ & 1,72 & 0,042 & 0,99 & $\mathbf{0 , 0 2 0}$ & 0,44 & $\mathbf{0 , 0 8 2}$ & 1,62 & 0,070* & 1,80 & $\mathbf{0 , 0 8 1} *$ & 1,74 & $0,069 *$ & 1,70 \\
\hline $\begin{array}{l}\text { Average effect on } \\
\text { the not treated }\end{array}$ & 0,022 & 0,43 & $0,113 * *$ & 2,18 & 0,071 & 1,46 & $\mathbf{0 , 0 7 3}$ & 1,41 & $\mathbf{0 , 0 3 2}$ & 0,61 & 0,008 & 0,14 & $\mathbf{0 , 1 0 3} *$ & 1,71 & 0,056 & 1,25 & 0,074 & 1,42 & $0,076^{*}$ & 1,72 \\
\hline $\begin{array}{l}\text { Average effect on } \\
\text { the treated }\end{array}$ & $-0,015$ & 0,39 & 0,069 & 1,49 & $0,066 * *$ & 2,08 & $0,080^{* * *}$ & 2,32 & $0,068^{*}$ & 1,84 & 0,049 & 1,19 & 0,031 & 0,72 & $0,100 * *$ & 2,07 & $0,100 *$ & 1,91 & 0,048 & 0,93 \\
\hline
\end{tabular}

